\title{
The Effect of Interactive Whiteboard Supported Inquiry- Based Learning on Achievement and Motivation in Physics and Views of Prospective Teachers Toward the Instruction
}

\author{
Uğur SARI* \& Gamze Bakır GÜVEN \\ Kırıkkale University, Kırıkkale, TURKEY
}

Received: 28.05 .2013

Accepted: 05.10 .2013

Abstract - In this study, the effects of interactive whiteboard supported inquiry- based learning approach on the academic achievement and motivation in modern physics teaching have been investigated and the views of prospective teachers toward the teaching supported by interactive whiteboard have been defined. In this study, patterned in the form of quasi-empirical model and supported with pre- and post-test control groups, data were collected by academic achievement tests, motivation scales and semi-structured interview forms. While traditional method was used to deliver lectures to the control group, interactive white board was used to deliver experimental group lectures enriched with activities such as simulations, videos and animations. Thus, it has been taken advantages of technology support in the processes of orienting and asking questions, identification of problems, hypothesis generation, testing and planning. In addition to these, the processes of measuring, drawing a graphs, controlling the variables and data interpretation have also been supported by simulations in lectures. As a result of applications, it has been achieved that the teaching materials used in experimental group significantly increased the students' motivations and academic achievements. Moreover, it also has been obtained that prospective teachers had positive opinions; such as funny (amusing) lecture environment, increasing the participation, concretization of the abstract concepts, facilitating the learning and providing permanence on applications in this study.

Key Words: Physics teaching, inquiry-based learning, interactive whiteboard, simulations, motivation, academic achievement.

DOI No: http://dx.doi.org/10.12973/nefmed204

\footnotetext{
* Corresponding author: Uğur SARI, Assoc. Prof. Dr., Department of Primary Science Education, Faculty of Education, Kırıkkale University, Kırıkkale, Turkey.

E-mail: usari05@yahoo.com
}

Note: This study was produced from master thesis of Gamze Bakır Güven 


\section{Summary}

Introduction: Especially in recent years, the studies show that the inquiry-based learning is a basic approach in the teaching of science. Inquiry learning moving away from the traditional approach of a universal and procedural scientific method is to encourage students to participate in a range of activities in which students construct and evaluate scientific knowledge (McGinn \& Roth, 1999). The basic purpose of this approach which defines the teacher as a consultant is to improve students skills on accessing the information rather than transferring existing knowledge. It is plain that technology products emerging from the rapid developments in information technologies have provided significant opportunities for inquirybased learning processes. Considering the importance of inquiry based learning approach and the supports provided by technological products, necessity of using both of these emerges the effective physics teaching. In brief, aims of this study are to investigate the effects of inquiry based learning integrated with technological products such as interactive whiteboard, simulations, animations and videos on student's academic achievements and motivations and to determine the views of prospective teachers about inquiry based learning supported with interactive whiteboard.

Methodology: In study, quasi experimental design with pre-test post-test control group is used. While the lectures were delivered by traditional methods to control group, the lectures enriched with inquiry learning approach based activities developed by the researchers were delivered by interactive whiteboard to experimental group. The quantitative data were collected by academic achievement tests and motivation scales, and for qualitative data collection, semi-structured interview forms were used in the experimental group. The sample of the study is composed of $1062^{\text {nd }}$ grade undergraduate students (53 pupil for experimental, 53 pupil for control group) who are in two different classes of modern physics courses in Department of Science Education of Kirlkkale University during the spring term of 20112012 academic year. Independent sample t-test is used in order to find out the relationship between experimental and control groups' pre-test post-test academic achievement and the level of motivation. The content analysis method was used to analyze the qualitative data.

Results: While there was no significant difference between the scores of pre-test academic achievement of the experimental and control group, a significant difference between the scores of the post-test in favor of the experimental group. In parallel with these changes in academic achievement scores, significant differences between the total scores of post-test motivation scale of the control and experimental groups were obtained in favor of the 
experimental group. These results show that the interactive whiteboard supported inquirybased learning approach is more effective on students' academic achievement and motivation compared to traditional methods. Also, the themes such as success, motivation, benefits, innovation, and visualization were reached from the views of prospective teachers about inquiry based learning supported with interactive whiteboard. Under the themes, it is found out that prospective teachers had positive views; such as funny (amusing) lecture environment, increasing the participation, concretization of the abstract concepts, facilitating the learning and providing permanence, increasing the motivation and achievement.

Discussion and Conclusions: Inquiry based physics teaching with interactive whiteboard was found to be more effective than traditional method on students' academic achievement and motivation in this study. After the applications while the achievement score of students in control group increased by $59.93 \%$, the rate of increase in score of students in the experiment group was as high as $91 \%$. In parallel with the changes while motivation score in the control group increased by $7.37 \%$, motivation scores of the experimental group rose by $24.55 \%$. Moreover, teacher candidates generally expressed positive opinions about interactive whiteboard supported instructional practices and $94.3 \%$ of teachers stated that they wanted to use it in classes if available. The reason of their desire was interactive whiteboard benefits such as providing entertainment course environment, getting attention, increasing attendance and motivation and concretizing the abstract concepts. Furthermore, all the candidate teachers participating in the study emphasized that preparation of course material was necessary for effective use of interactive whiteboard. When analyzing previous researches in literature, there are similar findings which inquiry-based instruction as well as interactive whiteboard applications increase the academic achievement, attitude, and motivation (Saka \& Akdeniz, 2006; Timur \& Kıncal 2010; Sünkür, Arabacı, \& Şanl1, 2012). However, there are also results showing that use of interactive whiteboard has no significant effect on academic achievement of elementary science teacher candidates (Emre, Kaya, Özdemir \& Kaya, 2011; Akbaş \& Pektaş, 2012) but the white board was used with the traditional approach in these studies and observed to have no effect on the success. The findings of this study indicates the importance of the integration of interactive white board for a learning approach in order to get the desired efficiency in education (Adigüzel \& Yüksel, 2012). 


\title{
Etkileşimli Tahta Destekli Sorgulamaya Dayalı Fizik Öğretiminin Başarı ve Motivasyona Etkisi ve Öğretmen Adaylarının Öğretime Yönelik Görüşleri
}

\author{
Uğur SARI $^{\dagger}$ ve Gamze Bakır GÜVEN \\ Kırıkkale Üniversitesi, Kırıkkale, Türkiye \\ Makale Gönderme Tarihi: 28.05.2013 \\ Makale Kabul Tarihi: 05.10.2013
}

Özet - Bu çalışmada, sorgulamaya dayalı öğrenme yaklaşımına uygun etkileşimli tahta destekli modern fizik ögretiminin akademik başarı ve motivasyona etkisi incelenmiş ve öğretmen adaylarının etkileşimli tahta destekli öğretime yönelik görüşleri belirlenmiştir. Ön test-son test kontrol gruplu yarı deneysel model biçiminde desenlenmiş araştırmada akademik başarı testi, motivasyon ölçeği ve yarı yapılandırılmış görüşme formları aracılığıyla veriler toplanmıştır. Kontrol grubunda geleneksel yöntemle dersler yürütülürken deney grubunda araştırmacılar tarafindan geliştirilen simülasyonlar, video görüntüleri ve animasyonlarla zenginleştirilmiş etkinlikler etkileşimli tahta ortamında sunulmuştur. Böylece soru sorma ve yönlendirme, problem tespiti, hipotez oluşturma, test etme ve planlama süreçlerinde teknoloji desteğinden yararlanılmıştır. Ayrıca simülasyonlar ile ölçme, grafik çizme, değişkenleri kontrol etme ve verileri yorumlama süreçleri de desteklenmiştir. Uygulamalar sonucunda deney grubunda kullanılan öğretim materyallerinin öğrencilerin motivasyonlarını ve akademik başarılarını önemli ölçüde artırdığı belirlenmiştir. Ayrıca öğretmen adaylarının uygulamaya yönelik; dersi eğlenceli hale getirme ve katılımı artırma, soyut kavramları somutlaştırma, öğrenmeyi kolaylaştırma ve kalıcılık sağlama şeklinde olumlu görüşlere sahip olduğu belirlenmiştir.

Anahtar kelimeler: Fizik öğretimi, sorgulamaya dayalı öğretim, etkileşimli tahta(akıllı tahta), simülasyon, motivasyon, akademik başarı.

\section{Giriş}

Son yıllarda gerçekleştirilen eğitim reformlarında öğretmen merkezli öğretimden daha çok öğrenenlerin kendi öğrenmelerinden sorumlu olduğu öğretim anlayışına yönelik vurgular artmıştır. Güçlü bir öğrenme ortamında; öğrencilerden öğretmen yorumlarını tekrarlamaktan ziyade kendi bilgilerini yapılandırmayı öğrenmeleri beklenilmektedir (Vreman-de, 2004). Bu tür yaklaşımlardan biri de fen öğretiminde temel bir yaklaşım olarak görülen ve öğrencilerin

\footnotetext{
${ }^{\dagger}$ İletişim: Uğur SARI, Doç. Dr., Fen Bilgisi Eğitimi Anabilim Dalı, Eğitim Fakültesi, Kırıkkale Üniversitesi, Kırıkkale, Türkiye.

E-mail: usari05@yahoo.com
}

Not: Bu çalışma Gamze Bakır GÜVEN'in tamamlanmış yüksek lisans tezinden üretilmiştir. 
sorular sorarak, araştırarak ve bilgileri analiz ederek verileri yararlı bilgilere dönüştürme süreci olarak tanımlanan sorgulamaya dayalı öğrenme yaklaşımıdır (Perry ve Richardson, 2001). Geleneksel öğrenme yaklaşımlarının tersine sorgulayıcı öğrenme, öğrencileri; bilimsel bilgileri oluşturmaktan değerlendirmeye uzanan bir aralıkta aktivitelere katılmaya motive eden bir süreçtir (McGinn ve Roth, 1999). Sorgulamaya dayalı öğretim tam ve kısmı sorgulayıcı olmak üzere ikiye ayrılır. Tam sorgulayıcı öğretimde öğrenciler kendi bilimsel sorularını üretir, sorulara cevaplarda kanıtlara öncelik verir, kanıtlardan açıklamalar üretir, açıklamalarıyla bilimsel bilgi arasında bağlantı kurar, iletişim kurar ve açıklamaları belirtir. Eğer sorgulamanın bu beş özelliğinden bir ya da daha fazlası öğretmen merkezli ise kısmi sorgulayıcı öğretim adını alır (Rushton, Lotter ve Singer, 2011).

Sorgulamaya dayalı öğretim uygulamalarının analizleri bilimsel sorgulamanın çeşitli formlarda ele alınabildiğini göstermektedir. Bell ve diğerleri (2010) literatür verilerinden yararlanarak sorgulama basamaklarını en geniş şekilde dokuz farklı kategori olarak tanımlamıştır. Bu kategoriler aşağıdaki gibi ifade edilebilir (Bell, Urhahne, Schanze ve Ploetzner, 2010);

Soru sorma ve yönlendirme, hemen hemen her zaman sorgulama basamaklarının ilkidir. Öğrenciler, ilgilerini çeken veya onlarda merak uyandıran bilimsel olguları inceler veya gözlem yaparlar. İdeal olarak sorularını kendileri geliştirirler. Bilimsel yöntemlerle hazırlanabilmek ve konu ile ilgili iyi soruyu oluşturabilmek zor aşamalardan birisidir.

Hipotez oluşturma, değişkenler arasındaki ilişkilerin formüle dökülmesidir. Bir hipotez sunmak, birçok öğrenci için zor bir faaliyettir. Sorgulama sürecinin başlangıç basamaklarında, öğrenciler genellikle bilimsel bakış açısıyla hangi öğelere ve niceliklere odaklanacağını bilmemektedirler. Bir başka problem ise öğrencilerin hatta üniversite öğrencilerinin bile basitçe bir hipotezin nasıl olması gerektiğini bilememesidir (de Jong ve van Joolingen, 1998).

Planlama, dar anlamda hipotezi test etmek için deney kurmayı ve hipotezin geçerliliğine karar vermek için uygun ölçüm aletlerini seçmeyi içermektedir. Daha geniş anlamda ise planlama, uygun meta-bilişsel stratejilerin kullanımını içermektedir. Açık sorgulamada öğrencilere, öğretmenlerinden bağımsız olarak kendi öğrendiklerini düzenleme firsatı verilir (Bell ve diğerleri, 2010).

Araştırma, doğal olaylara bağlı olarak, sorgulayıcı öğrenmenin deneysel durumudur. Bilgi, veri toplama araçlarının kullanımı, deneyin gerçekleştirilmesini ve veri havuzunun düzenlenmesini içerir. 
Verilerin analizi ve yorumlanmast, bir model önermek için, deneysel savların ve argümanların temelini oluşturur. Sıklıkla, zıt sonuçlarla karşılaşsalar bile öğrencilerin, verileri yorumlaması mevcut hipotezle uyumlu sonuçlanır. Bu olay “önyargılı doğrulama” olarak bilinir. Öğrenciler için bir diğer bilişsel sorun, grafiklerin yorumlanmasıdır (de Jong ve van Joolingen, 1998).

Model arama ve oluşturma, fen öğretiminin temel bir özelliğidir. Fen bilimlerinde modeller farklı amaçlar için kullanılır. Öğrenciler; keşfetmeyi, ortaya çıkarmayı, test etmeyi, gözden geçirmeyi ve içselleştirilmiş kendi mantıksal modellerini açıklayabilecek dışsallaştırılmış bilimsel modelleri kullanmayı öğrenmelidirler (Gobert ve Tinker, 2004).

Sonuçlandırma ve değerlendirme bir diğer kategoridir. Öğrenciler, sonuçlandırma ve değerlendirme faaliyetlerinde, kendi sorgulamalarından sonuçları süzüp alırlar. Sonuçlar, modeller, teoriler ve diğer deneylerle karşılaştırılarak verilerden elde edilebilir. Değerlendirme, öğrencilerin kendi araştırmalarını irdelemeye yardımcı olan yansıtıcı bir süreçtir. Öğrenciler kendi araştırma sonuçlarını yeni bir probleme uygulandığı zaman, sonuçlarının teori ile uyuşup uyuşmadığını veya yeniden ele alınıp alınamayacağını değerlendirmeyi öğrenirler (Bell ve diğerleri, 2010).

İletişim; sorgulayıcı öğrenmenin işbirlikçi unsurunu temsil eder. İletişim, araştırma sorusunun geliştirilmesinden başlayarak sonuçların sunumu veya raporlanması ile biten diğer bilimsel sorgulama süreçlerinin hepsine yayılan bir süreçtir. İletişim esnasında, öğrenciler kendi çalışmalarını yansıtmaya zorlanmalıdırlar.

Öngörü (tahmin) aşaması öğrencilerin hipotez sırasında değişkenlerin ilişkileri vurgulandığında, sistemin dinamikleri hakkındaki kanaatlerini açıkladığı aşamadır. Bu son kategori aynı zamanda, araştırma sonucunda yeni soruların ve hipotezlerin ortaya çıktığı sonuçlandırmaya ulaştıktan sonra bitirilmemiş sorgulama sürecini de sembolize edebilmektedir. Bu yüzden bazı araştırmacılar bilimsel sorgulamayı bir döngü olarak sunmayı tercih ederler (Schwarz ve White, 2005).

Uygulamalarda bu süreçler değişkenlik gösterebilir. Ancak genel anlamda; soru sorma ve yönlendirme başlangıçta, deney yapma gibi ortaya çıkarma süreci ortada ve sonuçlandırma ve değerlendirme gibi faaliyetler ise sonda bulunmaktadır (Bell ve diğerleri, 2010). Öğretmeni rehber olarak tanımlayan sorgulamaya dayalı öğretimde temel amaç, öğrencilere mevcut bilgileri aktarmaktan ziyade bilgiye ulaşma becerilerini kazandırmaktır. Şüphesiz bilişim teknolojilerindeki hızlı gelişmelerle birlikte ortaya çıkan teknoloji ürünleri; sorgulamaya dayalı öğrenme süreçlerinde önemli firsatlar sağlamıştır. Eğitim alanında yaşanan bu iki 
eğilim, teknoloji destekli ve sorgulamaya dayalı öğretiminin bir arada kullanılması ile ilgili araştırmaları da beraberinde getirmiştir. Birçok eğitim araştırma ve geliştirme projelerinde bilimsel verilerin toplanması, analizi ve yorumlanmasında bilgisayarların kullanımı araştırılmıştır (Edelson, Gordin ve Pea,1999). Bell ve diğerleri (2010) literatürde yer alan makalelerden yararlanarak sorgulamaya dayalı öğrenme yaklaşımının önemi, özellikleri ve sorgulama süreçlerinin her birinde bilgisayar araçlarının nasıl kullanıldığını açıklamışlardır. Blumenfeld ve diğerleri (1991) ise teknolojinin sorgulamaya dayalı öğrenme süreçlerine katkısını tanımlamışlardır. Teknoloji ürünlerinin fizik öğretimde kullanımı açısından üzerinde en çok durulan ve araştırılan alanlardan biri de simülasyonların kullanımıdır (Jaakkola, Nurmi, ve Veermans, 2011; Rutten, Joolingen, ve Van der Veen, 2012; Ulukök, Çelik ve Sarı, 2012). Simülasyonlar, anlatılması ve gözlenmesi zor, hatta imkânsız olan kavram ve olguları öğrenciye aktarılmasında önemli imkânlar sunar. Öğrencilerin öğrenme sürecinde aktif bir rol alması durumunda simülasyonlar sorular oluşturma, hipotez geliştirme, veri toplama gibi süreçleri içeren otantik sorgulama faaliyetlerini destekleyebilir (Rutten ve diğerleri, 2012). Son y1llarda öğretim sürecinde dikkatleri üzerine çeken bir başka teknoloji ürünü ise etkileşimli tahta "interactive whiteboard" kullanımı olarak görülmektedir. Akıllı tahta olarak ta isimlendirilen bu teknolojinin öğrenme-öğretme sürecini desteklediğini işaret eden bir çok araştırma mevcuttur. Smith, Higgins, Wall ve Miller (2005) çalışmalarında etkileşimli tahtanın öğrenme-öğretme sürecinde bir potansiyele sahip olduğunu ve olumlu yönde etkili olduğunu ifade etmişlerdir. Somyürek, Atasoy ve Özdemir (2009) ise etkileşimli tahtanın öğrenci merkezli işbirliği ortamı kurabilmek için önemli bir firsat sunduğunu, böylece öğrencilerin başarılarını arttırmalarına ve performans paritelerine destek sağladığını belirtmişlerdir. Öte yandan teknoloji ürünlerinin öğrenme-öğretme sürecinde kullanımına yönelik son yıllarda yapılan çalışmalarda, teknolojinin pedagojik anlayıştan soyutlanarak verimli olmasının mümkün olmadığı ve eğitimin amacına ulaşabilmesi için öğrenme ortamında teknolojinin uygun pedagojik yaklaşımlarla bütünleştirilerek birlikte kullanılması gerektiği belirtilmektedir(Chai, Koh, Tsai ve Tan, 2011; Adıgüzel ve Yüksel 2012).

\section{Araştırmanın Amacı ve Önemi}

Fizik dersini öğrenmenin zor olduğu bir çok araştırma sonuçlarında ifade edilmektedir. Öğrenciler fizik derslerinde varlığı bilinen ancak gözle tam olarak görülemeyen soyut kavramları anlamakta zorluk çekerler (Sencar, Yılmaz, ve Eryılmaz,2001; Yıldırım,Yalçın, Şensoy ve Akçay, 2008). Özellikle fotoelektrik olay, siyah cismin 1şıması, compton olayı gibi soyut kavramlar içeren konuların öğrenciler tarafından anlaşılması oldukça güçtür. Bu tür 
kavramlar anlatılırken öğrencilerin görsel ve düşünsel yapılarını harekete geçirebilecek öğretim aktivitelerinin geliştirilip kullanılması oldukça önemlidir (Taş, Köse ve Çepni, 2006). Dolayısıyla bu konularla ilgili sınıf ortamında gerçekleştirilemeyen deneyler ve ders konusunun günlük yaşamla ilişkilendirilmesini sağlayan örnekler, video görüntüleri ve animasyonların bilgisayar ortamında sunulması önemli firsatlar sağlayacaktır. Teknoloji desteğiyle yürütülen eğitimin amacına ulaşabilmesi ise uygun öğrenme-öğretme yaklaşımı ile bütünleştirilmesi suretiyle mümkün gözükmektedir. Aynı zamanda etkili bir fizik öğretiminin öğrencilerin fiziğe karşı tutumlarını artırması ve farklı şekillerde öğrenmeye teşvik etmesi gereklidir (Zacharia, 2003). Sorgulamaya dayalı öğrenme yaklaşımının önemi ve teknoloji ürünlerinin sağladığı destekler düşünüldüğünde etkili bir fizik öğretiminde her ikisinin birlikte kullanılmasının gereği ortaya çıkmaktadır. Ayrıca öğretmen adaylarıyla yürütülecek nitelikli çalışmalar, hem onların etkili öğrenmeleri hem de öğrenciyi aktif kılan teknoloji ile bütünleştirilmiş öğretim uygulamalarını pekiştirmesine katkıda bulunması açısından büyük önem taşımaktadır.

$\mathrm{Bu}$ bilgiler 1şığında çalışmanın amacı fen bilgisi öğretmenliği programı 2. sınıf Modern Fiziğe Giriş dersi kapsamında etkileşimli tahta, simülasyon, animasyon ve video görüntüleri gibi teknoloji ürünleri ile bütünleştirilmiş sorgulamaya dayalı öğretimin öğrencilerin akademik başarı ve motivasyonlarına etkisini incelemek ve öğretmen adaylarının etkileşimli tahta destekli sorgulamaya dayalı öğretime yönelik görüşlerini belirlemektir.

\section{Yöntem}

\section{Araştırma Modeli}

Çalışmada ön test son test kontrol gruplu yarı deneysel model kullanılmıştır (Karasar, 2003). Kontrol grubunda geleneksel yöntemle dersler işlenirken deney grubunda ise araştırmacılar tarafından geliştirilen sorgulayıcı öğrenme yaklaşımına uygun etkileşimli tahta destekli etkinliklerle dersler yürütülmüştür. Araştırmanın nicel verileri akademik başarı testi ve motivasyon ölçeği aracılığıyla, nitel verileri ise deney grubuna uygulanan yarı yapılandırılmış görüşme formu aracılığıyla toplanmıştır. Araştırmanın evreni, 2011-2012 eğitim-öğretim yılı bahar dönemi Kırıkkale Üniversitesi Eğitim Fakültesi İlköğretim Bölümü Fen Bilgisi Öğretmenliği Programı ikinci sınıfında öğrenim gören 53 normal öğretim ve 53 ikinci öğretim öğrencisi olmak üzere toplam 106 öğrenciden oluşmuştur. 
Veri Toplama Araçları

Modern Fizik Akademik Başarı Testi (MFABT): Öğrencilerin modern fizik dersindeki akademik başarılarını ölçmek amacıyla akademik başarı testi geliştirilmiştir. Testteki sorular Serway Fizik 3 (Ed: Çolakoğlu, 1996), Kuantum Fiziğine Giriş (Dikici, 1994) ve Modern Fiziğe Giriş (Özdoğan, Kara, Gümüş ve Orbay, 2011) kaynaklarından yararlanılarak araştırmacı tarafından geliştirilmiştir. 43 soruluk taslak testin kapsam ve görünüş geçerliğine ilişkin, birisi dersi yürüten öğretim üyesi olmak üzere üç uzmandan görüş alınmıştır. Böylece 27 soruya indirilen taslak test bir üst sınıfta öğrenim gören 82 öğrenciye uygulanmıştır. Madde ayırt ediciliği 0.20 değerinin altında kalan ve madde güçlük dereceleri $0,00-0,19$ (çok güç) arasında olan sorular ile 0,80 - 1,00 (çok kolay) arasında olan sorular elenerek (Turgut, 1997) 23 soruluk MFABT hazırlanmıştır (Ek 1). Testin ortalama güçlük değeri 0,45 olarak hesaplanmış ve KR-20 (Kuder Richardson-20) güvenirlik katsayısı 0,78 olarak bulunmuştur. Testten alınabilecek maksimum puan 23, minimum puan ise 0 dir.

Öğretim Materyalleri Motivasyon Ölçeği (ÖMMÖ): Öğretmen adaylarının motivasyon düzeylerini belirlemek ve deney grubunda kullanılan öğretim materyallerinin motivasyon düzeylerine etkisini incelemek amacıyla Keller tarafından 2010 yılında geliştirilen ve Jale Balaban Salı tarafindan Türkçe'ye çevrilen 36 maddelik 5'li likert tipi ölçek kullanılmıştır (Balaban, 2002). Dikkat (Attention), İlişki (Relevance), Güven (Confidence) ve Doyum (Satisfaction) şeklinde dört alt boyuttan oluşan ölçekte ilgi için 12 madde, ilişki için 9 madde, güven için 9 madde ve doyum için 6 madde bulunmaktadır (Keller, 2010). Ölçekte alınabilecek maksimum puanlar ilgi için 60 , ilişki ve güven için 45 , doyum için 30 ve toplamda 180 puandır. Bu çalışmada ölçeğin Cronbach Alpha iç tutarlılık katsayısı $\alpha=0,88$ olarak tespit edilmiştir.

Etkileşimli Tahta Uygulamaları Durum Değerlendirme Formu(ETDDF): Öğretmen adaylarının etkileşimli tahta destekli öğretim uygulamalarıyla ilgili görüşlerini değerlendirmek amacıyla yarı yapılandırılmış görüşme formu hazırlanmıştır. Formdaki sorular, etkileşimli tahtanın etkililiği, kullanışlılığı, öğrenme düzeyine katkısı, motivasyona etkisi, simülasyonların faydaları ve materyal geliştirmenin önemine ilişkin durumları içerecek şekilde hazırlanmıştır. Hazırlanan form iki alan uzmanın görüşü ile kapsam geçerliliği gözden geçirildikten sonra 8 soruya indirilerek son hali verilmiştir (Ek 2).

\section{Öğretim Materyallerinin Geliştirilmesi ve Uygulama}

Çalışma, Fen Bilgisi Öğretmenliği Programı ikinci sınıf düzeyinde Modern Fiziğe Giriş dersinde yer alan "Işık, Siyah Cismin Işıması, Fotoelektrik Olay, Compton olayı, 
Parçacıkların Dalga Özelliği” konuları kapsamında gerçekleştirilmiştir. Hem deney hem de kontrol grubundaki dersler aynı öğretim üyesi tarafindan yürütülmüş ve uygulama haftada 2 saat üzerinden 8 hafta sürmüştür. Dersler kontrol grubuna geleneksel yöntemlerle işlenmiş; öğretim üyesi genellikle konuyu düz anlatım yolu ile sunmuş, bazen de soru-cevap yöntemi kullanılmıştır. Derslerde, Serway Fizik 3 (Ed: Çolakoğlu, 1996), Kuantum Fiziğine Giriş (Dikici, 1994) ve Modern Fiziğe Giriş (Özdoğan, 2011) kitaplarından yararlanılarak oluşturulan ders notları kullanılmış genellikle konularla ilgili klasik problemler çözülmüşsür. Ders içerisinde normal tahta ve bazı konularda da sunum amaçlı bilgisayar kullanılmıştır. Deney grubunda ise sorgulamaya dayalı öğrenme yaklaşımına uygun olarak hazırlanan bilgisayar destekli etkinlikler ders içeriğini oluşturmuştur. Simülasyon, animasyon, video görüntüleri ile desteklenmiş etkinlikler, öğrencilerin aktif katılımı ile birlikte etkileşimli tahta kullanılarak gerçekleştirilmiştir.

\section{Deney Grubu İçin Hazırlanan Öğretim Materyalleri}

Deney grubunda, sorgulamaya dayalı öğretimin uygulanma sürecinde 7E öğrenme halkası modelinden yararlanılmıştır. Bu modele uygun etkinlikler Willis'in (1994) Öğretimsel Geliştirme Süreci-Modeline göre hazırlanmıştır. Öğretim materyalinin içeriğinin hazırlanması, düzenlenmesi ve geliştirilmesi süreçlerinde iki uzman görüşüne başvurulmuş ve gerekli düzenlemeler yapılmıştır. Microsoft Office Publisher programı ile hazırlanan materyalde yer alan etkinliklerde, Colorado Üniversitesi Fizik Eğitim Teknolojisi (PhET) projesi kapsamında geliştirilen, 1şık ve renkler, dalga girişim, moleküller ve 1şık, siyah cisim 1şıması ve fotoelektrik olay simülasyon yazılımları (http://phet.colorado.edu/tr/simulations/category/physics) kullanılmıştır. Bu yazılımlar Türkçe’ye uyarlanmış ve öğrencilerin ilgili deneyleri sanal ortamda kendilerinin gerçekleştirebileceği niteliktedir. Deneyler esnasında değişken değişimi ve kontrolü araçlar menüsü kullanarak yapılabilmektedir. Ayrıca gerekli ölçüm değerleri ölçü araçları tarafından verilmekte, gerektiğinde grafik araçları yardımıyla grafikler çizdirilebilmekte ve böylece veriler değerlendirilebilmektedir. Çalışmada 7E modeline göre hazırlanan materyalin(Ek 3) aşamaları ve uygulama süreci aşağıda verilmiştir.

1. Merak Uyandırma (Ön Bilgileri Ortaya Çıkarma-Dikkat Çekme, Motive etme): $\mathrm{Bu}$ basamakta öğrencilerin önbilgilerini ortaya çıkarmak, dikkatini çekmek, beyin firtınası oluşturmak ve motivasyonlarını sağlamak amacıyla sınıf ortamında gerçekleştirilemeyen deneyler ve ders konusunun günlük yaşamla ilişkilendirilmesini sağlayan örnekler, video görüntüleri ve animasyonların etkileşimli tahta ortamında sunulması planlanmıştır. Böylece soru sorma ve yönlendirme süreci desteklenmeye çalışılmıştır. 
2. Keşfetme: $\mathrm{Bu}$ basamakta daha çok laboratuvar ortamında yapılamayan deneylerin etkileşimli tahta kullanılarak sanal uygulamalarının gerçekleştirilmesi planlanmıştır. Sorgulayıcı öğrenme kapsamında problemin tespiti, hipotezlerin oluşturulması ve test edilmesi, planlama ve araştırma süreçlerinde teknoloji desteğinden yararlanma yoluna gidilmiştir. Öğrenciler problemlere uygun hipotezler geliştirmiş ve bu hipotezleri simülasyonlar yoluyla test etme imkânı bulmuştur. Simülasyon içeriğinde bulunan ölçüm araçları ve grafik araçları kullanılarak verilerin analizi ve yorumlama süreçleri bilgisayar destekli olarak gerçekleştirilmiştir.

3. Açıklama: Bu aşamada konu gerekli bilgi, simülasyonlar ve animasyonlardan yararlanılarak açıklanmış ve öğrencinin varsa eksik bilgilerini tamamlaması amaçlanmıştır. Keşfetme basamağında kullanılan sanal deneyler zaman zaman tekrar açıklama amacıyla kullanılmış, öğrenciler arasında tartışma ortamı oluşturulmuş, deney sonuçlarının ve bulguların yorumlanması sağlanmıştır.

4. Genişletme: Öğrencilerden bu aşamaya kadar edinildiği düşünülen beceri ve kazanımların farklı bir deney, problem ve alıştırmaya teknoloji desteği ile uygulaması planlanmıştır. Öğrencilerin önceki bilgilerini ve araştırmalarını kullanması beklenilmiştir. $\mathrm{Bu}$ amaçla bilgilerini kullanabilecekleri problem çözme, verilen bilgiyi formülize etme ve yorum yapma etkinlikleri hazırlanarak uygulanmıştır.

5. İlişkilendirme: Öğrenciler açısından, bilgilerinin kullanım alanı bulması konunun değerli kılınması sağlar. $\mathrm{Bu}$ nedenle etkinliklerde, her konuyu günlük hayatla ilişkilendiren animasyon, video görüntüleri ve görsel resim içeriklerine yer verilmiştir.

6. Fikir Alış-Verişi: $\mathrm{Bu}$ aşamada bilgilerin yeniden yorumlanarak tartışılmasını sağlamak üzere kilit sorular sorulmuştur. Bu amaç doğrultusunda daha çok açık uçlu sorular hazırlanmış ve öğrencilerin bir tartışma ortamında kavramlar hakkında bilgi paylaşımı yapması sağlanmıştır.

7. Değerlendirme: Etkinlikler süresince edinilen beceri ve kazanımlar süreç boyunca ve sonuçta teknoloji desteği ile değerlendirilmesi planlanmıştır. Simülasyon uygulamaları sürecinde grafik araçlarından yararlanılmış, konunun sonunda ise çoktan seçmeli, eşleştirmeli sorular ve tanılayıcı dallanmış ağaç tekniği gibi geleneksel ve alternatif değerlendirme teknikleri bir arada kullanılmıştır. Hazırlanan etkinlikler etkileşimli tahta kullanılarak gerçekleştirilmiştir. 


\section{Verilerin Analizi}

Nicel araştırma verilerinin analizinde SPSS 16.00 programından yararlanılmıştır. Deney ve kontrol gruplarının ön test- son test akademik başarı ve motivasyon düzeyi puanları arasında anlamlı bir ilişkinin olup olmadığını belirlemek için bağımsız grup t-testi analizleri uygulanmıştır. Değişkenler arasında anlamlılık düzeyi $p<0,05$ kabul edilmiştir. Ayrıca etki büyüklüğü olarak isimlendirilen, bağımsız değişkenin ya da faktörün bağımlı değişkendeki toplam varyansın ne kadarını açıkladığını gösterir eta-kare $\left(\eta^{2}\right)$ değeri hesaplanmıştır. Bu değer, 0,00 - 1,00 arasında değişir ve .01, .06 ve .14 düzeyindeki $\eta^{2}$ değerleri, aynı sırayla "küçük", "orta” ve "geniş" etki büyüklüğü olarak yorumlanır (Büyüköztürk, 2010). Nitel araştırma verilerin analizinde ise içerik analizi yöntemi kullanılmıştır. İçerik analizinde temel amaç, toplanan verileri açıklayabilecek kavramlara ulaşmaktır (Yıldırım ve Şimşek, 2011). Buradan hareketle içerik analizinde elde edilen verilerden kodlar, bu kodlara ait temalar ve bu temalar içinde yer alacak alt temalar oluşturulmuştur. Kategorileştirme işleminin son hali alanda uzman iki öğretim üyesi tarafından değerlendirmeye tabii tutulmuş ve gerekli düzenlemeler yapıldıktan sonra son halini almıştır. Bu çalışmada öğrencilerin kimlikleri saklı tutulmuş ve her birine Ö1, Ö2,... şeklinde numara verilmiştir.

\section{Bulgular ve Yorumlar}

\section{Modern Fizik Akademik Başarı Testine İlişkin Bulgular ve Yorumlar}

Tablo 1'de görüldüğü gibi uygulama öncesi kontrol ve deney gruplarının akademik başarıları arasında anlamlı bir farklılık yoktur. Bu bulgular deney ve kontrol gruplarının ön bilgilerinin eşit olduğunu göstermektedir.

Tablo 1 Ön test akademik başarı puanlarına ilişkin bağımsız gruplar t-testi sonuçları

\begin{tabular}{|c|c|c|c|c|c|c|c|}
\hline Gruplar & $\mathrm{N}$ & $\bar{x}$ & SS & $\mathrm{Sd}$ & $\mathrm{t}$ & $\mathrm{p}$ & $\eta^{2}$ \\
\hline Kontrol & 53 & 5,79 & 2,755 & \multirow{2}{*}{104} & \multirow{2}{*}{0,191} & \multirow{2}{*}{, 849} & \multirow{2}{*}{0,00035} \\
\hline Deney & 53 & 5,70 & 2,300 & & & & \\
\hline
\end{tabular}

Uygulamalar sonrasında deney ve kontrol gruplarının son test akademik başarı puanları t-testi sonuçları ise Tablo 2'de verilmiştir. Burada kontrol grubu ile deney grubunun akademik başarıları arasında deney grubu lehine anlamlı bir farklılık görülmektedir. Etki büyüklüğü olarak isimlendirilen eta-kare $\left(\eta^{2}\right)$ değeri 0,076 olarak hesaplanmıştır. Bu değer 
deney grubunda yapılan uygulamaların akademik başarı üzerinde "orta" dereceden fazla etki büyüklüğüne sahip olduğunu göstermektedir (Büyüköztürk, 2010).

Tablo 2 Son test akademik başarı puanlarına ilişkin bağımsız gruplar t- testi sonuçları

\begin{tabular}{lccccccc}
\hline Gruplar & $\mathrm{N}$ & $\bar{x}$ & $\mathrm{ss}$ & $\mathrm{Sd}$ & $\mathrm{t}$ & $\mathrm{p}$ & $\eta^{2}$ \\
\hline Kontrol & 53 & 9,26 & 2,761 & \multirow{2}{*}{104} & 2,922 & \multirow{2}{*}{004} & 0,076 \\
\hline Deney & 53 & 10,89 & 2,953 & & & &
\end{tabular}

Her iki gruba da konu kapsamları aynı olacak şekilde aynı öğretim üyesi ile dersler işlenmesine rağmen deney grubunun akademik başarı puan ortalamasının daha yüksek olduğu görülmektedir. $\mathrm{Bu}$ farkın nedeni; kullanılan öğretim modeline uygun geliştirilen ve simülasyonlar, video görüntüleri, animasyonlar içeren etkinliklerin öğrencilerin aktif katılımıyla etkileşimli tahta ortamında gerçekleştirilmesi ve böylece ilgi, motivasyon ve katılımla birlikte başarının artması olarak değerlendirilebilir. Özellikle laboratuvar ortamında araç-gereçle gerçek deneylerinin yapılamadığı siyah cisim 1şıması, compton olayı, fotoelektrik olay gibi konularla ilgili simülasyonları öğrencilerin etkileşimli tahta ile doğrudan gerçekleştirmesi sonucu anlamlı ve kalıcı öğrenmenin sağlandığı düşünülmektedir.

\section{Öğretim Materyalleri Motivasyon Ölçeğine İlişkin Bulgular ve Yorumlar}

Deneysel uygulamaya başlamadan önce deney ve kontrol gruplarında Modern Fiziğe Giriş dersi bir aylık süre boyunca aynı yöntemle(geleneksel yöntem) işlenmiş, daha sonra her iki gruba da ÖMMÖ ön test uygulaması yapılmıştır. Tablo 3'de verilen bağımsız gruplar ttesti sonuçlarına göre ön testte elde edilen kontrol ve deney grubu Dikkat, İlişki, Güven, Doyum ve Toplam puanları arasındaki görülen puan farkları istatistiksel olarak anlamsızdır $(\mathrm{p}>0.05)$.

Tablo 3 Ön test ÖMMÖ puanlarına ilişkin bağımsız gruplar t-testi sonuçları

\begin{tabular}{|c|c|c|c|c|c|c|c|c|}
\hline & Grup & $\mathrm{N}$ & $\bar{x}$ & SS & $\mathrm{t}$ & sd & $\mathrm{p}$ & $\eta^{2}$ \\
\hline & Kontrol & 53 & 35.47 & 7.82 & & & & \\
\hline \multirow[t]{2}{*}{ Dikkat } & Deney & 53 & 36.92 & 6.41 & 1.046 & 104 & .300 & 0,01 \\
\hline & Kontrol & 53 & 25.85 & 4.49 & & & & \\
\hline \multirow[t]{2}{*}{ İlişki } & Deney & 53 & 25.85 & 4.49 & .563 & 104 & .570 & 0,003 \\
\hline & Kontrol & 53 & 24.32 & 5.05 & & & & \\
\hline \multirow[t]{2}{*}{ Güven } & Deney & 53 & 24.13 & 4.13 & .211 & 104 & .830 & 0,0004 \\
\hline & Kontrol & 53 & 17.81 & 3.84 & & & & \\
\hline \multirow[t]{2}{*}{ Doyum } & Deney & 53 & 17.32 & 3.71 & .669 & 104 & .500 & 0,004 \\
\hline & Kontrol & 53 & 103.45 & 17.68 & & & & \\
\hline Toplam & Deney & 53 & 103.74 & 14.80 & .089 & 104 & .930 & 0,00007 \\
\hline
\end{tabular}


ÖMMÖ ön test uygulamasıyla birlikte deneysel çalışmaya başlanmış ve kontrol grubunda dersler aynı yöntemle devam ederken deney grubunda ise geliştirilen etkinlikler etkileşimli tahta ile uygulanmıştır. Çalışmanın sonunda her iki gruba son test uygulaması yapılmış ve bulgular Tablo 4'te verilmiştir.

Tablo 4 Son test ÖMMÖ puanlarına ilişkin bağımsız gruplar t-testi sonuçları

\begin{tabular}{|c|c|c|c|c|c|c|c|c|}
\hline & Grup & $\mathrm{N}$ & $\bar{x}$ & SS & $\mathrm{t}$ & $\mathrm{sd}$ & $\mathrm{p}$ & $\eta^{2}$ \\
\hline & Kontrol & 53 & 37.45 & 7.70 & & & & \\
\hline \multirow[t]{2}{*}{ Dikkat } & Deney & 53 & 45.77 & 7.88 & 5.50 & 104 & .000 & 0,225 \\
\hline & Kontrol & 53 & 27.04 & 4.49 & & & & \\
\hline \multirow[t]{2}{*}{ İlişki } & Deney & 53 & 32.68 & 5.63 & 5.49 & 104 & .000 & 0,225 \\
\hline & Kontrol & 53 & 27.55 & 4.80 & & & & \\
\hline \multirow[t]{2}{*}{ Güven } & Deney & 53 & 29.15 & 5.19 & 1.65 & 104 & .100 & 0,025 \\
\hline & Kontrol & 53 & 19.04 & 4.07 & & & & \\
\hline \multirow[t]{2}{*}{ Doyum } & Deney & 53 & 21.62 & 4.42 & 3.13 & 104 & .000 & 0,086 \\
\hline & Kontrol & 53 & 111.08 & 17.74 & & & & \\
\hline Toplam & Deney & 53 & 129.23 & 20.85 & 4.83 & 104 & .000 & 0,183 \\
\hline
\end{tabular}

Bağımsız gruplar t-testi sonuçlarına göre son testten elde edilen Dikkat, İlişki, Doyum ve Toplam puanlarında kontrol grubu ile deney grupları arasında görülen puan farkları deney grubu lehine istatistiksel olarak anlamlıdır $(\mathrm{p}<0,05)$. Buna karşın "güven" puanında gözlenen farklılık istatistiksel olarak anlamsızdır ( $\mathrm{p}>0,05)$. Ayrıca; Tablo 4'de belirtilen eta-kare $\left(\eta^{2}\right)$ değerleri hesaplanmış ve p anlamlılık düzeyine paralel olarak "güven" hariç diğer değişkenlerde etki büyüklüğü "doyum” için "orta", "dikkat” ve "ilişki” için ise "geniş" derece üzerinde çıkmıştır. Bu sonuçlara göre, deney grubunun motivasyon seviyeleri, kontrol grubuna göre daha olumlu derecede yükselmiştir. Deney ve kontrol grubunun özellikle derse olan "dikkat" ve "ilişsi”” puanlarında büyük fark görülmektedir. Bu farkın deney grubunda uygulanan simülasyon, animasyon, video görüntüleri ve etkileşimli tahta uygulamalarından kaynaklandığı düşünülmektedir. Etkinliklerde, öğrencilerin dikkatini çekmek, motivasyonlarını sağlamak amacıyla laboratuvar ortamında gerçekleştirilemeyen deneylerin simülasyonlar yoluyla sunulması, ders konusunun günlük yaşamla ilişkilendirmesini sağlayan örnekler, video görüntüleri ve animasyonların etkileşimli tahta ile sunulması derse olan ilgi, dikkat ve motivasyonu arttırmıştır. Deney grubu ile kontrol grubu öğrencilerinin "güven" puanları arasında anlamlı bir fark çıkmamasının sebebi; deney grubu öğrencilerinin, etkileşimli tahta ile ilk defa karşılaşmaları, bilgisayar kullanımındaki yetersizlikleri ve bu nedenle de kaygı duymaları ve güven duygusunun oluşmaması düşünülmektedir. 
Nitel Bulgular ve Yorumlar

Deney grubu öğrencilerinin öğretime yönelik görüşleri, etkileşimli tahta ve simülasyon uygulamaları altında iki genel kategoride değerlendirilerek temalar ve kodlar belirlenmiş ve bu kodlar üzerinden öğrenci görüşlerine de doğrudan atıf yapılarak yorumlanmıştır. Etkileşimli tahta uygulamalarına ait tema ve bu temalara ilişkin alt boyutlar tekrar eden frekans sayılarına dayalı olarak en yüksek katılımdan aşağıya doğru Tablo 5 'te verilmiştir.

Tablo 5 Etkileşimli tahta uygulamalarına ait ana tema ve alt temalar

\begin{tabular}{|c|c|}
\hline TEMA & ALT TEMA \\
\hline \multirow{4}{*}{ BAŞARI } & - Kalıcılık \\
\hline & - $\quad$ Etkinlikler \\
\hline & - $\quad$ Anlatım Kolaylığ1 \\
\hline & - Uygulama Kolaylığ1 \\
\hline \multirow{3}{*}{ MOTIVASYON } & - $\quad$ Zevk Alma \\
\hline & - Odaklanma \\
\hline & - $\quad$ Güven Duyma \\
\hline \multirow{3}{*}{ YENİLIK } & - $\quad$ Etkileşimli Tahta Kullanma Kaygısı \\
\hline & - $\quad$ Kullanılan Öğretim Modelinin Etkililiği \\
\hline & - $\quad$ Endişe Duyma \\
\hline \multirow{2}{*}{ FAYDA } & - $\quad$ Not Alma Alışkanlığ \\
\hline & - $\quad$ Merak Uyandırma \\
\hline
\end{tabular}

"Etkileşimli tahta, dersi anlama düzeyine ve öğrenmene ne gibi katkl sağladı?" sorusuna karşılık öğrenci görüşleri incelendiğinde en çok katılımın, etkileşimli tahta uygulamalarının sunduğu firsatlarla ilişkili olarak başarı teması altında toplandığı görülmektedir (Tablo 6). Bu alanda öğrencilerin en çok üzerinde durduğu konu ise animasyon, video görüntüleri gibi görsel materyallerin ve simülasyon uygulamalarının öğrenmelerinde etkili olduğu ve kalıcı öğrenmeler sağladığı yönünde olmuştur. Öğrencilerin yarıdan fazlası etkileşimli tahtanın öğrenme kolaylığı sağladığı yönünde görüş belirtmişlerdir. Konuyla ilgili bazı öğrencilerin görüssleri; 'Gerek simülasyonlar gerekse konu sonu alıştırmalar sayesinde öğrenmeyi kolaylaştırdığını düşünüyorum' (Ö41), 'Konunun çeşitli videolarla ve örneklerle açıklanmış olması görsellik açısından zenginlik katıyor. Buda anlamayı kolaylaştırıyor' (Ö18), 'Görselliğin artmastyla ve birebir temasla ögrendiğimiz için bilgileri daha çabuk öğrenmemizde büyük yararı var' (Ö11), 'Görselliğe hitap ederek ilgimi çekti ve düşünmeme yardımcı oldu' (Ö51) şeklindedir. Öğrenciler, gerek etkileşimli tahta ortamının sunduğu imkan gerekse öğretim modelinin gereği hazırlanan etkinlikler kapsamında 
dersin görsel materyallerle desteklenmesi neticesi olarak öğrenmelerinin kolaylaştığını vurgulamışlardır.

Tablo 6 Başarı teması altında ortaya çıkan alt temalar ve kategoriler

\begin{tabular}{|c|c|c|c|}
\hline TEMA & ALT TEMA & KODLAR & FREKANS (f) \\
\hline \multirow{13}{*}{ BAŞARI } & \multirow{3}{*}{ Kalıcılık } & Öğrenme kolaylığ1 & 28 \\
\hline & & Görsel materyallerin kullanılması & 18 \\
\hline & & Öğrenme hızı & 3 \\
\hline & \multirow{5}{*}{ Etkinlikler } & Derse katılım & 14 \\
\hline & & Alıştırma yapma & 5 \\
\hline & & Yaparak öğrenme & 5 \\
\hline & & Tekrar sayısı & 4 \\
\hline & & Eksiklerin tamamlanması & 1 \\
\hline & \multirow[b]{2}{*}{ Anlatım Kolaylığı } & Anlaş1lır olma & 23 \\
\hline & & Kavramların analizi & 4 \\
\hline & \multirow{3}{*}{ Uygulama Kolaylığı } & Ders süresini etkin kullanma & 12 \\
\hline & & Deney yapabilme imkanı & 8 \\
\hline & & Ders süresini etkin kullanamama & 3 \\
\hline
\end{tabular}

Bir başka boyutta öğrenciler etkileşimli tahta ile gerçekleştirilen etkinliklere dikkat çekerek bu etkinliklerin derse katılımlarını büyük oranda arttığını ve öğrenmelerine olumlu katkı sağladığını belirtmişlerdir. $\mathrm{Bu}$ duruma ilişkin olarak 'Dikkatimi daha rahat toplayabiliyorum, derse daha rahat katılabiliyorum' (Ö21); 'Normal tahtada öğretmen sürekli anlatıyordu. Etkileşimli tahtada bizimde katkımız oldu’ (Ö45) görüşleri belirtilmiştir. 'Öğrencilerin ilgisini arttırdı ̆̆ gibi, aktif katılım sayesinde öğretmen adaylarının bireysel gelişimine de katkı sağlayacaktır' (Ö44) şeklinde görüşüyle hem kendine hem de meslek hayatlarına nasıl katkıda bulunacağını belirtmişlerdir.

Öğrenci görüşlerinden çıkan önemli sonuçlardan birisi de etkileşimli tahtanın anlatım kolaylığı sunduğu düşüncesidir. \%52 oranında öğrenci, etkileşimli tahtanın ve beraberinde kullanılan materyallerin öğrenme isteklerini, ilgilerini ve motivasyonlarını arttırarak dersi daha iyi anlamalarını sağladığını ifade etmişlerdir. Bu konuda öğrenciler, 'Önceden nasıl anlayacă̆ım konusunda korkum vardı ama etkileşimli tahta, simülasyonlar kullanıldı̆̆ için terimleri doğru, net anlamada daha yararlı oldu' (Ö1), 'Öğretmene çok yardımcı oldu bu sayede bize bilgilerini daha anlaşıllı bir şekilde sundu ve neticede dersi anlamamı kolaylaştı' (Ö16), 'Öğrenmemin arttı̆ğ kesindir. Okuyarak öğrenemediğim konuları görsel olarak daha iyi anlamaya başladım' (Ö12) ifadelerini belirtmişlerdir.

Başarı teması altında öğrencilerin üzerinde durduğu bir başka konu ise ders süresinin etkili kullanıldığı inancı olmuştur. Öğrenciler; 'Daha hızlı ders işleniyor çizmeyle, yazmayla uğraşmıyorduk' (Ö9), 'Önceden ders işlenip sonra çizilip, yazılıp açıklanırken şimdi zaman kaybı olmadan daha ĕglenceli, yapılandırıcı şekillerle sonuçları gözlemlemek olumlu oldu' 
(Ö32) şeklinde görüş belirtmişlerdir. Buna karşın üç öğrenci, 'Dersler daha önceki anlatım tarzına nazaran ilgi çekici ancak zaman kaybına sebep olduğunu düşünüyorum' (Ö44), 'Ben bilgisayara karşı tepkiliyim. Sadece ders süresinin uzadığını düşünüyorum. Ama görsel olarak bazı sahneler aklımda. Tepkili olmama răgmen yine de dikkatimi çekti ve anlatılanları anladım' (Ö27) şeklinde olumsuz görüş belirtmişlerdir. Bu öğrenciler alış1lmış öğrenme anlayışına (pasif dinleyici rolü) bağlı olarak uygulamaya tepkili yaklaşmakta ve zaman kaybı olarak değerlendirmektedir. Ayrıca öğrenciler uygulama kolaylığı boyutunda simülasyonların etkileşimli tahta ile kendileri tarafından gerçekleştirilmesinin önemli firsatlar sağladığını belirtmişlerdir: 'Etkileşimli tahtada laboratuvar ortamında kolay gerçekleştiremeyeceğimiz bir takım deneyleri sanal gerçeklik yardımıyla somutlaştırarak daha kolay anlama firsatımız oldu' (Ö46), 'Teoride olan deneyleri sanal ortamda da olsa görülmesi anlama düzeyini olumlu etkiledi' (Ö36), 'Deneyler sanal alemde daha rahat ve güvenilir yapıldı̆̆g için ilgi ve alakam o yöne doğru ĕgilime başladı. Doğal olarak da motivasyonum, derse ilgim arttı' (Ö12).

Etkileşimli tahta uygulamalarıyla ilgili başarı temasından sonra öğrencilerin en çok dile getirdikleri tema motivasyon olmuştur (Tablo 7). Öğrenciler, "Etkileşimli tahta kullanımı derse karşı ilgi ve motivasyonunu nasıl etkiledi?" sorusuna \%94,3 oranında olumlu yönde etkilediğini belirtmişlerdir.

Tablo 7 Motivasyon ana temasından elde edilen alt temalar, kodlar ve frekanslar

\begin{tabular}{llll}
\hline TEMA & ALT TEMA & KODLAR & FREKANS (f) \\
\hline & & Eğlenceli ders ortamı & 20 \\
\multirow{3}{*}{ MOTIVASYON } & Zevk Alma & Kullanışlilık & 13 \\
& & Materyal çeşitliliği & 12 \\
& & Öğrenme isteği & 2 \\
\cline { 2 - 4 } & Odaklanma & Dikkati yoğunlaştırma & 11 \\
\cline { 2 - 4 } & Güven Duyma & Çalışma isteği & 2 \\
\hline
\end{tabular}

Motivasyon teması altında öğrencilerin üzerinde en çok durduğu konu etkileşimli tahta uygulamalarıyla sunulan animasyon, video görüntüsü, simülasyon gibi materyallerin ve gerçekleştirilen etkinliklerin eğlenceli bir öğrenme ortamı sunması ve bu ortamın motivasyonlarını olumlu yönde etkilemesi olmuştur. Birçok öğrenci etkileşimli tahta uygulamalarının dersleri daha zevkli hale getirdiğini belirterek bu durumu öğretmen olduğunda etkileşimli tahtayı kullanmak isteme nedeni olarak göstermiştir. Bir öğrenci 'Öğretmen olduğumda etkileşimli tahta kullanmak isterim çünkü onların ilgisini çekecek, gerekirse komik görsellerle hem dersi sevdirebilirim hem de başarı oranını arttırabilirim diye düşünüyorum' (Ö28) şeklinde görüş bildirirken bir başka öğrenci 'Derse istekli ve sevecen 
geliyorum. Önceden biraz can sıkıntısı oluyordu. Sürekli not alarak ve dinleyerek geçiyordu. Şimdi hem sınıf arkadaşlarımla hem de hocamla birlikte dersi işleyiş durumu zevkli oluyor' (Ö3) şeklinde görüş bildirmiştir. Öğrenciler dersin eğlenceli geçmesiyle o dersten alınan verim arasında ilişki kurmuş ve ne kadar zevkli bir ders işlenirse o kadar öğrenmenin de kolay gerçekleşeceğini belirtmişlerdir. Ayrıca öğrenciler etkinliklere katılmalarının, yani derste aktif olmalarının motivasyon, tutum ve başarılarında etkili olduğunu düşünmektedirler.

Öğrenciler etkileşimli tahta ile yürütülen derslerde materyal zenginliğinin önemine dikkat çekerek etkileşimli tahtanın kara tahta gibi kullanılmasının bir fayda sağlamayacağını ve dersin zengin materyallerle desteklenmesi gerektiğini vurgulamışlardır. Bu konuda öğrenci görüşleri, 'Bir ögrretmen adayı olarak yapılan fizik dersinden etkilendiğimden dolayı etkileşimli tahtanın derslerde etkili kullanımı için materyal hazırlanmasının gerekli olduğunun kanaatindeyim. Görsel ifadeler, videolar, animasyon ilgimi arttırdı ve ders notumda yararını görmüş oldum' (Ö7), 'Eğer uygun materyal hazırlanmazsa dersi kara tahtada işlemekle etkileşimli tahtada işlemek arasında fark kalmaz' (Ö48), 'Etkileşimli tahtanın derslerde etkili kullanımı için daha çok materyal hazırlanmalı çünkü görsellik arttıkça anlama, yorumlama ve hatırlama daha kolay oluyor' (Ö2) şeklindedir. Bu boyutta öne çıkan konulardan biri de öğrencilerin etkileşimli tahtayı sağladığı imkanlar dolayısıyla kullanışlı bulması olmuştur. Öğrenciler, 'Etkileşimli tahta dersi anlama düzeyine olumlu yönde katkılar săglamıştır. Normal kullandı̆̆ımız tahtalara göre daha kullanışlıdır ve öğrenme özelliği çoktur, çok amaçlı kullanılabilir' (Ö25), 'Öğretmenin ders işleyişini kolaylaştırdı' (Ö33) ifadeleriyle gerek ders işlenişinde gerek öğrenme durumlarında kolaylık sağladığı görüşünü bildirmişlerdir. Öğrencilerden bazıları ise 'Daha önce işlediğimiz derslerde belirli bir süreden sonra dikkat dă̆ınıklı̆̆ı olabiliyordu. Sesli sunum ve görsellikler dikkat çekici. Resim veya videolar derse ilgiyi arttırıp, sınıfin sessizliğini sağlayıp herkesin yönelmesini sağllyor' (Ö46), 'Etkileşimli tahta kullanımı derse karşı ilgimizi arttırdı ve olumlu yönde etkiledi. Kullanırken dikkatimizi daha çok veriyor ve bir noktada yoğunlaşıyoruz' (Ö24) ifadeleriyle etkileşimli tahtanın dikkati artırdı̆̆ını belirtmişlerdir.

Öğretmen adayları, "Öğretmen olduğunda derslerinde etkileşimli tahta kullanmak ister misin? Neden?" sorusuna \%94,3 oranında olumlu görüş bildirmiş ve kullanmak isteme nedeni olarak ise eğlenceli ders ortamı sunma, görsellik sağlama, dikkat çekme, motivasyon ve derse katılımı artırma ve soyut konuları somutlaştırma gibi nedenler belirtmişlerdir. Buna karşın etkileşimli tahta kullanımında yetersiz olacağına inanan \%5,7 oranında öğretmen adayı ise olumsuz görüş bildirmiştir. Öğrencilerin ilk defa etkileşimli tahta ile karşılaşmaları ve bazı 
öğrencilerin bilişim teknolojilerine karşı olumsuz beceri ve tutuma sahip olmaları onlarda bazı kaygılar oluşturmuştur. Buna karşın etkileşimli tahta ile birlikte geleneksel öğretimin dışında öğrenci merkezli bir öğretim modelinin uygulanmasının olumlu etkileri belirlenmiştir. $\mathrm{Bu}$ alandaki bulgular yenilik teması altında toplanmış ve üç alt boyutta incelenmiştir (Tablo 8).

Tablo 8 Yenilik temasindan elde edilen alt temalar, bulgular ve frekanslar

\begin{tabular}{|c|c|c|c|}
\hline TEMA & ALT TEMA & KODLAR & FREKANS (f) \\
\hline \multirow{3}{*}{ YENILIK } & $\begin{array}{l}\text { Etkileşimli Tahta } \\
\text { Kullanma Kaygısı } \\
\end{array}$ & $\begin{array}{l}\text { Bilgisayar kullanımındaki } \\
\text { yetersizlikler }\end{array}$ & 12 \\
\hline & $\begin{array}{l}\text { Kullanılan Öğretim } \\
\text { Modelinin Etkililiği }\end{array}$ & Ezberci anlayışı silme & 5 \\
\hline & Endişe Duyma & $\begin{array}{l}\text { Sinav uygulama } \\
\text { sistemiyle uyuşmaması }\end{array}$ & 1 \\
\hline
\end{tabular}

Etkileşimli tahta uygulamalarıyla ilgili en çok katılımın olduğu olumsuz durum öğrencilerin kullanabilme kaygısı olmuştur. Öğrenciler, 'Etkileşimli tahta ilk defa uygulandığ için öğrencilerin stres yapmasına, korkmasına neden oldu' (Ö33), 'Daha önce anlatım tarzına nazaran ilgi çekici ancak zaman kaybına sebep olduğunu düşünüyorum. Öğrenci kullanmayı bilmiyor"'(Ö34), 'Öğretmen olduğumda derslerimde etkileşimli tahta kullanmak istemem. Çünkü kullanamam' (Ö6) ifadelerini kullanmışlardır. Deney grubunun etkileşimli tahta ile ilk defa karşılaşmaları ve böylece kullanım konusunda özellikle uygulamanın başında zorlanmış olmaları, derse katılımda ve tahtanın kullanımında endişe yaratmış ve zamanı etkin kullanma konusunda verimsizlik gibi bir yargıya sebep olmuştur.

"Etkileşimli tahta ile yürütülen dersler ile önceki derslerinizi karşılaştırdı̆̆ınızda ne gibi farklılıklar görüyorsunuz?” sorusuna daha çok ezberci anlayışı silme gibi olumlu yönde farklılık belirtilmiştir. Öğrenciler, 'Önceki derslerde sırf ezbere dayalı bilgi vardı. Uygulama alanında etkileşimli tahta çok yararlı' (Ö46), 'Etkileşimli tahta ile yürütülen dersler ile önceki dersleri karşılaştırdığımda farklılık var. Çünkü diğer türlü derslerde sınava yakın zamanda ezberliyoruz ve sonra unutuyoruz. Böyle görsel şeyler sayesinde motivasyonum ve derse olan ilgim arttı' (Ö51), Etkileşimli tahta ile yürütülen dersler ile önceki dersleri karşılaştırdı̆̆ımda farklılık kesinlikle var, bilgiyi daha net bir şekilde hayatla bağdaştırarak aldığımızı düşünüyorum' (Ö7) şeklinde görüş bildirmişlerdir. Bu görüşlerden etkileşimli tahta ile bütünleştirilmiş sorgulamaya dayalı öğretimin motivasyon ve öğrenmelerinde etkili olduğunu söyleyebiliriz.

Öğrenci görüşlerinden ortaya çıkan temalardan biri de "Not Alma Alışkanlığı" ve “Merak Uyandırma” şeklinde iki alt boyuttan oluşan “Fayda” temasıdır (Tablo 9). 
Tablo 9 Fayda temasindan elde edilen alt temalar, kodlar ve frekanslar

\begin{tabular}{cllc}
\hline TEMA & \multicolumn{1}{c}{ ALT TEMA } & KODLAR & FREKANS (f) \\
\hline \multirow{3}{*}{ FAYDA } & Not Alma Alışkanlığı & Etkili not tutma & 5 \\
\cline { 2 - 4 } & & Not tutamama & 5 \\
& \multirow{2}{*}{ Merak Uyandırma } & Günlük hayatla iliş̧ki kurabilme & 3 \\
& & Sorgulama & 3 \\
& & Keşfetme imkanı & 1 \\
\hline
\end{tabular}

Öğrencilerden beş tanesi etkileşimli tahta ile zamanın etkili kullanıldığı yönünde olumlu görüş bildirirken beş öğrenci not tutma alışkanlığını ortadan kaldırdığı yönünde olumsuz düşünceye sahiptir. Bir öğrenci 'Daha önce yazarken dinlemekten feda ediyordum. Ama artık yazmak yerine daha çok dinleyip, daha iyi öğreniyorum. Yazmaya giden vaktimi dinlemeye ayırlyorum' (Ö37) görüşünü bildirirken bir başka öğrenci, 'Etkileşimli tahta ile yürütülen derslerde öncelikle yazl yazmak gibi bir dert tamamen ortadan kalklyor. Sadece ögretmenin vurguladı̆̆ önemli noktaları not almak daha kolayıma geliyor. Fakat bir süre sonra bu not alma alışkanllğı kayboluyor' (Ö4) görüşüne sahiptir. Bu görüşlerden bazı öğrencilerin öğrenmelerinde görselliği ön plana çıkarırken bazı öğrencilerin ise sınav kaygısı nedeniyle not tutamama endişesine kapıldığı görülmektedir. Öğrenciler daha önceki derslerde sadece dinleyici olduklarından ders notu tutma konusunda zorluk çekmiyorlard1. Ancak etkileşimli tahta ile yürütülen derslerde aktif olarak katıldıklarından not tutamama endişesi ile karşı karşıya kaldıkları düşünülmektedir.

Öğrencilerden bazıları ise etkileşimli tahta ile gerçekleştirilen etkinliklerin sorgulama, düşünme, anlama, günlük hayatla bağdaştırarak bilgiyi anlamlı kılma gibi fayda sağladığını ifade etmişlerdir. Bu konuda öğrencilerin görüşleri, 'Etkileşimli tahta öğrenme konusunda daha kolay hatırlama să̆ladı derse de etkili katılarak anlama să̆ladı. Burada daha çok düşünce ve zihin hareketi yaşandı' (Ö49), 'Kendimiz tahtada yaparak ya da arkadaşlarımız yaparak, düşünerek, sorgulayarak yapmamızı sağladı' (Ö51), Etkileşimli tahta ile yürütülen dersler ile önceki dersleri karşılaştırdı̆̆ımda farklılık kesinlikle var, bilgiyi daha net bir şekilde hayatla bağdaştırarak aldı̆̆ımızı düşünüyorum' (Ö7) şeklindedir. Bu ifadelerden öğrenciyi düşünmeye sevk eden, konuyu kendilerinin keşfetmesine imkan tanıyan etkinliklerin aktif katılımlarıyla gerçekleştirilmesi, bilgilerin günlük hayattaki kullanım örneklerinin görülmesi dersi daha anlamlı kıldığı ve öğrenmeyi daha etkili hale getirdiği söylenebilir. Bu katkıların aslında daha çok 7E öğretim modeli ve kullanılan animasyon, video görüntülerinden ortaya çıktığı düşünülmektedir. Ancak öğrenciler etkileşimli tahtayı öğretim modeli ve kullanılan materyaller ile bir bütün olarak değerlendirmişlerdir. 
Simülasyon uygulamalarına yönelik öğrenci görüşleri değerlendirildiğinde "Uygulama durumu" ve "Görsellik" şeklinde iki tema oluşmuştur (Tablo 10).

Tablo 10 Simülasyon uygulamalarına ait ana tema, alt tema, kodlar ve frekanslar

\begin{tabular}{|c|c|c|c|}
\hline TEMA & ALT TEMA & KODLAR & KANS (f) \\
\hline \multirow{8}{*}{ UYGULAMA DURUMU } & \multirow{4}{*}{$\begin{array}{l}\text { Bilginin } \\
\text { desteklenmesi }\end{array}$} & Kalıcılık & 18 \\
\hline & & Anlaș1lır olma & 14 \\
\hline & & Öğrenme kolaylığ 1 & 9 \\
\hline & & Günlük hayatla ilişki kurma & 3 \\
\hline & \multirow{4}{*}{$\begin{array}{l}\text { Dersin verimliliğine } \\
\text { olan katkısı }\end{array}$} & Soyut kavramların somutlaştırılması & 24 \\
\hline & & Deney ve gözlem yapabilme & 4 \\
\hline & & Keşfetme & 1 \\
\hline & & Ders süresini etkin kullanma & 1 \\
\hline \multirow[b]{2}{*}{ GÖRSELLİK } & \multirow{2}{*}{$\begin{array}{l}\text { Memnuniyet ve } \\
\text { beklentiyi karşılama }\end{array}$} & Eğlenceli ders ortamı sunma & 4 \\
\hline & & Dikkati yoğunlaștırma & 1 \\
\hline
\end{tabular}

"Simülasyon uygulamaları senin için faydalı oldu mu? Olduysa ne gibi faydaları olduğunu belirtiniz." sorusuna yönelik simülasyonların sağladığı faydalar arasında en çok üzerinde durulan konu soyut kavramların somutlaştırılması noktasında olmuştur. Öğrenciler, 'Etkileşimli tahtada laboratuvar ortamında kolay gerçekleştiremeyeceğimiz bir takım deneyleri sanal gerçeklik yardımıyla somutlaştırarak daha kolay anlama firsatımız oldu' (Ö36), 'Simülasyon uygulamalarl faydalı oldu. Dersi anlamamda somut hale getirmesi en büyük faydadır' (Ö46) görüşünü belirtmişlerdir. Bir öğrenci ise simülasyon uygulamalarına yönelik soruya, 'Etkileşimli tahta sayesinde öğrendiklerimiz soyut kalmıyor. Bazı şeyleri zihnimizde canlandırmamıza yardımcı oluyor. Bilgileri görsel olarak kesinlikle daha iyi aktarıyor' (Ö40) ifadesini kullanarak aslında etkileşimli tahta ve simülasyonların bir bütün olarak değerlendirildiği sonucunu vermiştir. $\mathrm{Bu}$ ifadelerde görüldüğ̈̈ gibi öğrenciler hem etkileşimli tahta ile ilgili sorulara hem de simülasyon uygulamaları ile ilgili sorulara soyut kavramların somutlaştırılmasını sağladı şeklinde cevap vermişılerdir. Etkileşimli tahta, hazırlanan materyaller sayesinde soyut kavramların somutlaştırılmasını sağlarken simülasyonlar deneyleri sanal ortamda yapmalarını sağlayarak somutlaştırmaya yardımcı olmuştur. Ayrıca bazı öğrenciler 'Simülasyon uygulamaları benim için faydalı oldu. Laboratuvar ortamında yapıp göremediğimiz deneyleri bize daha kalıcı şekilde gösterdi' (Ö34), 'Simülasyon uygulamalarını öğretmen olduğumda kullanmak isterim. Okulumda belki laboratuvar koşullarından yararlanamazsam simülasyonlardan yararlanarak öğrencilerime daha kalıcı bilgi vermek isterim' (Ö34), 'Bazen yapılması zor olan ya da ortam koşullarından kaynaklanan sorunlardan dolayı veya yapması uzun olan deneyleri simülasyon yaparak daha iyi ve tehlikesiz yapabilme olanağı sağladı' (Ö37) yönünde görüş belirtmişlerdir. Bu görüşler, 
laboratuvar ortamında yapılması zor, tehlikeli yada imkansız olan deneylerde simülasyonların tercih nedeni olabileceğini göstermektedir. Simülasyonların teorik bilginin uygulamaya dönüşmesi ve bilginin desteklemesi bakımından oldukça faydalı görüldüğü söylenebilir.

Simülasyon uygulamalarının sağladığı fayda ve öğretmen olduğunda tercih edilme nedenleri arasında gösterilen bir diğer konu ise kalıcılık boyutunda olmuştur. Bu konuda öğrenciler, 'Simülasyon uygulamaları benim için faydalı oldu. Konunun adını duyduğumda direk ders esnasındaki videolar, simülasyon uygulamaları gözümde canlandı' (Ö8), 'Simülasyon uygulamalarını öğretmen olduğumda kullanmak isterim. Konuyu daha iyi aktarırım ve kalıcılık să̆lamış olurum' (Ö40), 'Öğrencilerin duyu organına hitap ederek bilgi düzeyi daha üst seviyede tutularak, ögrenme kalıcı olur' (Ö42) şeklinde görüş belirtmişlerdir. $\mathrm{Bu}$ ifadelerle öğrenciler sanal deneyleri gerçekleştirerek, kalıcı öğrenmelerin sağlandığını açıkça vurgulamaktadırlar. Ayrıca bazı öğrenciler, 'Simülasyon uygulamaları benim için faydalı oldu. Daha iyi anlamamıza yardımcı oldu, olayın nasıl olduğunu görmüş olduk. Havada bir şeyler kalmadı' (Ö1), 'Simülasyon gerçekten anlamamızın çok zor olduğu konuları görsel olarak izlememiz sayesinde anlaşılır hale getirdi ve zorlanmadan konuları kafamızda oturtmamızı sağladı' (Ö52) görüşünü belirterek simülasyonlar sayesinde konuların daha anlaşılır olduğunu ifade etmişlerdir. Simülasyon uygulamalarına yönelik öğrenci görüşleri arasında yer alan, 'Simülasyon uygulamalarını öğretmen olduğumda kullanmak isterim. Öğrencilerin ilgisini çeker ve ders daha zevkli, daha anlaşılır, daha kolay bir ders haline gelir' (Ö13), 'Simülasyon uygulamaları benim için faydalı oldu. Hazırlayacağım ödevde benimde nasıl bir yol izleyeceğimi, izleyenlerin sılklmadan dersi dinlemelerini nasıl sağlayacă̆ımı görmüş oldum' (Ö12), 'Simülasyon uygulamaları ĕglenceli ve ögretici' (Ö26) ifadeleri simülasyon uygulamalarının "eğlenceli ders ortamı sunma" boyutunu ortaya çıkarmıştır. Öğrenciler dersi eğlenerek zevkle öğrendiklerini ifade etmişler ve bu durumu bu tür uygulamaları tercih nedeni olarak göstermişlerdir.

Etkileşimli tahta uygulamaları ile simülasyon uygulamalarına ait oluşturulan kodlar birbiri ile yakından ilişkilidir. Uygulamada kullanılan öğretim modeli de bu durumda oldukça etkilidir. Genel olarak öğrenciler etkileşimli tahta kullanımının öğrenmelerini olumlu etkilediğini, motivasyonlarının ve derse olan ilgilerinin dolayısıyla bu dersi başaracağına dair güven duygusunun geliştiğini belirtmişlerdir. Kavramların, sözel bilgilerin etkileşimli tahta sayesinde görselleştirilmesi dersi hem eğlenceli kılmakta hem de ders süresince öğrencilerin odaklanmalarını sağlamaktadır. Kullanılan öğretim modelinin gereği olarak etkinliklere fazlaca yer verilmiş olması öğrencinin ders katılımını oldukça artırmıştır. 


\section{Sonuç, Tartışma ve Öneriler}

$\mathrm{Bu}$ çalışmada sorgulamaya dayalı öğrenme yaklaşımına uygun etkileşimli tahta destekli modern fizik ögretiminin öğrencilerin akademik başarı ve motivasyonlarına etkisi incelenmiş, öğretmen adaylarının etkileşimli tahta destekli öğretime yönelik görüşleri belirlenmiştir. Deney ve kontrol grubu ön test akademik başarı puanları arasında anlamlı bir farklılık oluşmazken son test başarı puanları arasında deney grubu lehine anlamlı fark ortaya çıkmıştır. 0,076 olarak hesaplanan etki büyüklüğü değeri ise deney grubunda yapılan uygulamaların akademik başarı üzerinde "orta" dereceden fazla etki büyüklügüne sahip olduğunu göstermiştir. $\mathrm{Bu}$ sonuç etkileşimli tahta destekli sorgulamaya dayalı öğretimin geleneksel yönteme göre akademik başarı üzerinde daha etkili olduğunu göstermektedir. Uygulamaların içeriğini oluşturan konuların(fotoelektrik olay, siyah cismin 1şıması vb.) soyut kavramlar içermesi ve laboratuvar ortamında deneyleri gerçekleştirme imkanın olmaması etkileşimli tahta ortamında sunulan simülasyonları önemli hale getirmiştir. Bu deneylerin etkileşimli tahta ile öğrenciler tarafından sınıf ortamında gerçekleştirilmesi öğrencilere hipotezlerini test etme imkanı sunmuştur. Öğrenciler yazılımlarda mevcut ölçme, değişkenleri kontrol etme, grafik çizme seçeneklerini kullanarak verileri yorumlamış ve anlamlı öğrenme gerçekleşmiştir. Deney grubu öğrencilerinin uygulamaya yönelik görüşleri de bu bulguları destekler niteliktedir. Öğrenciler öğretim modelinin gereği olarak hazırlanan etkinliklerle ders konusunun günlük yaşamla ilişkilendirilmesini sağlayan örnekler, video görüntüleri ve animasyonların etkileşimli tahta ile sunulmasının başarıları üzerinde etkili olduğunu düşünmektedirler. Etkileşimli ortamda gerçekleştirilen etkinliklerin öğrenmeyi kolaylaştırdığını, soyut kavramları daha iyi yapılandırılıp somutlaştırıldığını ve anlaşılır hale getirdiğini, kalıcı öğrenmeler sağladığını ve böylece akademik başarıları üzerinde olumlu etki yarattığını ifade etmişlerdir.

Araştırmada akademik başarı puanlarının yanısıra kontrol grubu ve deney grubu öğrencilerinin motivasyon ölçeği son test toplam puanları arasında da deney grubunun lehine anlamlı farklılıklar elde edilmiştir. Öğrencilerinin dikkat, ilişki ve doyum puanları arasında anlamlı farklılıklar oluşurken güven puanları arasında anlamlı bir farklılık çıkmamıștır. Etki büyüklüğü ise "doyum” için "orta", "dikkat" ve "ilişki” için ise "geniş" derece üzerinde hesaplanmıştır. $\mathrm{Bu}$ bulgular deney grubunda kullanılan animasyon, video görüntüleri ve simülasyonlar ile zenginleştirilmiş etkinlikler ve bu etkinliklerin etkileşimli tahta uygulamalarının öğrencilerin motivasyonunu kontrol grubunda kullanılan power point sunum ve kara tahta uygulamaları gibi geleneksel yöntemlere göre önemli ölçüde arttırdığını 
göstermektedir. Öte yandan "güven” puanları arasında anlamlı bir fark çıkmamasının sebebi; deney grubu öğrencilerinin, etkileşimli tahta ile ilk defa karşılaşmaları nedeniyle kaygı duymaları olabileceği düşünülmektedir. Ayrıca öğrenci görüşleri de nitel verilerden elde edilen bu bulguları destekler niteliktedir. Öğrenciler, \%94,3 oranında etkileşimli tahta kullanımının derse karşı ilgi ve motivasyonlarını olumlu yönde etkilediğini belirtmişlerdir. Etkileşimli tahta uygulamaları sayesinde dersin daha eğlenceli hale geldiğini, gerçekleştirilen etkinliklerin ve görsel materyallerin derse karşı ilgi ve motivasyonlarının arttığını ifade etmişlerdir. \%5,7 oranında öğrenci ise etkileşimli tahta kullanma kaygısı nedeniyle olumsuz görüş belirtmişlerdir. Şüphesiz bir sınıfta öğretim uygulamaları öğrencinin öğrenmesi ve dolayısıyla da öğrenme sonuçları üzerinde etkilidir. Sorgulamaya dayalı öğretim yönteminin öğrencilere geleneksel öğretim yönetmelerine göre daha zengin ve bilimselliğe dayalı deneyimler sağladığı belirtilmektedir (Keselman, 2003). Ancak sorgulamaya dayalı öğrenmenin başarılı bir şekilde uygulanmasında öğrencilerin derse yeterince motive olamamaları gibi zorluklar vardır. Sorgulamanın uzun ve zorlu doğası gereği, birçok geleneksel eğitim faaliyetlerinin gerektirdiğinden daha yüksek motivasyon seviyesine ihtiyaç duyulmaktadır. Öğrenciler yeterince motive edilmemeleri, sorgulama faaliyetlerine katılmalarında başarısız olmalarına sebep olur (Edelson ve diğerleri, 1999). Dolayısıyla eğitimde temel bir faktör olarak görülen motivasyon fen bilimleri gibi anlamakta zorluk çekilen derslerde ihmal edilmeyen bir boyuttur. Bu çalışmada deney grubu öğrencilerinin motivasyon düzeylerinin önemli ölçüde artmış olması sorgulamaya dayalı öğretimin başarılı biçimde uygulandığını göstermektedir.

Araştırmada, öğrenme materyallerin uygulandı̆̆ sınıfta etkileşimli tahta ile bütünleştirilmiş sorgulamaya dayalı öğrenme yaklaşımının ilk kez uygulanıyor olması ve katılımcıların öğretmen adayı olmaları, onların öğretime ilişkin görüşlerini önemli kılmıştır. $\mathrm{Bu}$ konuda öğretmen adaylarının görüşleri değerlendirildiğinde gerek etkileşimli tahta uygulamalarının gerekse öğretim modelinin olumlu yansımaları görülmüştür. Öğrenci görüşlerinden uygulamalarla ilgili; başarı, motivasyon, fayda, yenilik, ve görsellik gibi başlıklarda oluşan temalara ulaşılmıştır. Bu temalar altında öğretmen adaylarının etkileşimli tahta uygulamalarına yönelik, öğrenme kolaylığı sağlama, soyut kavramları somutlaştırma, derse katılımı artırma, eğlenceli ders ortamı sunma, ilgi, motivasyon ve başarıyı artırma şeklinde olumlu görüşlere sahip olduğu belirlenmiştir. Öğrencilerden çoğu etkileşimli tahta uygulamalarından önce deneylerin yapılamayışı ve kavramların soyut olması nedeniyle anlamakta güçlük çektiğini ve olayları zihinlerinde canlandıramadıklarını ancak etkileşimli 
tahta uygulamalarıyla soyut kavramları somutlaştırdıklarını, deneyleri aktif katılımlarıyla yaparak daha iyi öğrendiklerini ifade etmişlerdir. Bu bulgular soyut kavramlar içeren fizik konularının anlaşılmasında gerek etkileşimli tahtanın gerekse sanal uygulamaların önemini göstermektedir (Rutten ve diğerleri, 2012; Jakkola ve diğerleri, 2011). Ayrıca öğrenciler daha önceki derslerde genelde dinleyici olduklarını etkileşimli tahta uygulamalarıyla derse katılımlarının arttığını ve böylece dersin daha eğlenceli hale gelerek öğrenmenin kolaylaştığını ifade ederek öğrenci-tahta etkileşimi ve öğrenciyi aktif kılan öğretim yönteminin önemini otaya koymuşlardır. \%94,3 gibi oldukça yüksek oranda öğrenci, öğretmen olduğunda derslerinde etkileşimli tahtayı kullanmak istediğini ifade etmiş ve kullanmak isteme nedeni olarak ise eğlenceli ders ortamı sunma, görsellik sağlama, dikkat çekme, motivasyon ve derse katılımı artırma ve soyut konuları somutlaştırma gibi nedenler belirtmişlerdir. Buna karşın etkileşimli tahta kullanımında yetersiz olacağına inanan \%5,7 oranında öğretmen adayı ise olumsuz görüş bildirmiştir. Öğretmen adaylarının görüş birliğinde olduğu bir konu ise etkileşimli tahtanın etkin kullanımı için ders materyalinin hazırlanma gereği hususunda olmuştur. Öğrenciler ders konusunun günlük yaşamla ilişkilendirilmesini sağlayan örnekler, video görüntüleri, animasyonlar, sanal deneylerin ve değerlendirme amaçlı hazırlanan etkinliklerin etkileşimli tahta ile sunulması yada aktif katılımlarıyla gerçekleştirmelerinin önemine vurgu yaparak bu tür etkinlikler hazırlanmadığında etkileşimli tahtanın çok yararlı olamayacağını düşünmektedirler. $\mathrm{Bu}$ bulgulardan etkileşimli tahta uygulamalarında görsel materyallerin ve öğrencilerin etkileşimli olarak gerçekleştirebilecekleri etkinliklerin oldukça önemli olduğu söylenebilir. Benzer düşünceler, derslerinde akıllı tahta kullanan öğretmenler tarafından da dile getirilmiştir (Türel, 2012). Öğrenci ifadelerinden ortaya çıkan bir başka durum ise etkileşimli tahta, simülasyonlar ve öğretim modeline yönelik görüşlerde bir ayırımın yapılamadığı ve bunların bir bütün olarak değerlendirildiği noktasında olmuştur. Öğrenciler bazı görüşlerinde simülasyonların etkisini yada öğretim modelinin gereği olarak hazırlanan etkinliği etkileşimli tahtanın bir getirisi gibi değerlendirirken bazı ifadelerde ise tersi durum oluşmuştur. Bu durum etkileşimli tahta ve sorgulamaya dayalı öğretim modelinin bütünleştirilmesinin önemini ortaya koymaktadır.

Literatüre baktığımızda araştırmada elde edilen bu bulguları destekler nitelikte gerek sorgulamaya dayalı öğretimin gerek simülasyonların gerekse etkileşimli tahta uygulamalarının akademik başarı, tutum ve motivasyonu artırdığına yönelik bulgular mevcuttur. Saka ve Akdeniz (2006) biyoloji dersinde animasyon ve simülasyonlardan oluşan 
öğretim materyallerini 5E modeline uygun etkinlikler içerisinde kullanarak öğrenme üzerine etkilerini incelemişler ve bütünleştirici öğrenme ortamında bilgisayar destekli etkinliklerin öğretmen adaylarında başarıyı yükselttiğini tespit etmişlerdir. Timur ve Kıncal (2010) ise çalışmalarında sorgulamalı öğretimin, geleneksel yöntemle karşılaştırıldığında öğrencilerin genel başarı düzeylerini anlamlı derecede arttırdığı sonucuna ulaşmıştır. Rutten ve diğerleri (2012) ise ERIC, Scopus ve ISI Web of Knowledge'de taranan 2001-2010 y1lları arasinda yayımlanmış toplam 510 makaleyi inceleyerek simülasyonların fen eğitimindeki etkilerini araştırmışlardır. İster geleneksel yöntemi geliştirmek için isterse geleneksel yöntemle kıyaslamak için olsun incelenen tüm makalelerde simülasyonların kullanımının olumlu sonuçlar verdiği görülmüştür. Etkileşimli tahtanın öğretim uygulamalarında kullanımına yönelik çalışmalarda ise bizim çalışmamızı destekler nitelikte öğrencilerin dikkat, ilgi, motivasyon ve başarılarını artırdığı ve öğrenmelerini önemli oranda geliştirdiklerine dair bulgular mevcuttur (Sünkür ve diğerleri, 2012; Marzano, 2009; Lai, 2010). Buna karşın Akbaş ve Pektaş (2011) ve Emre ve diğerleri (2011) ise çalışmalarında etkileşimli tahta kullanımının fen bilgisi öğretmen adaylarının akademik başarı üzerinde önemli bir etkiye sahip olmadığını tespit etmişlerdir. Deney ve kontrol gruplu öntest-sontest şeklinde desenlenmiş her iki çalışmada da kontrol grubunda geleneksel yöntem kullanılırken deney grubunda geleneksel yöntem içerisinde etkileşimli tahta kullanılmıştır. Bu çalışmada ise etkileşimli tahta ve sorgulayıcı öğretim bütünleştirilerek bir arada kullanılmış ve böyle bir öğretimin akademik başarı ve motivasyon üzerinde önemli derecede etkili olduğu görülmüştür. $\mathrm{Bu}$ durum öğrenme ürünleri üzerinde olumlu etkilerin gerçekleşebilmesi için etkileşimli tahtanın öğrenme-öğretme sürecinde tek başına yeterli olmadığını ve öğrenme ortamında uygun öğrenme modeliyle bütünleştirilmesinin son derece önemli olduğunu göstermektedir (Adıgüzel ve Yüksel, 2012).

Araştırmada elde edilen bulgular neticesinde şu önerilerde bulunulabilir;

Eğitim fakültelerinde öğrenme - öğretme yöntem ve tekniklerinin pedagojik alan eğitimi olarak verilmekle birlikte öğretim elemanları tarafından yürütülen alan derslerinde daha çok geleneksel yöntemlerin dışına çıkılamamaktadır. Bu durum ise öğretmen adaylarına, benimsenmesi gerekli öğrenme - öğretme yaklaşımları adına iyi örnek oluşturmamaktadır. Gerek akademik başarıyı arttırma gerekse öğretmen adaylarına model olma amacıyla fizik, kimya gibi lisans derslerinde bu tür öğretim uygulamaları artırılmalıdır.

FATİH projesi ile etkileşimli tahta, tablet bilgisayar ve internet ortamı gibi teknolojik ürünlerin öğrenme-öğretme sürecinde kullanılması planlanmaktadır. Bu teknoloji ürünlerinin 
öğrenme-öğretme sürecinde verimliliğini artırmak için uygun öğrenme-öğretme yaklaşımlarıyla bütünleştirilmesi gereklidir. Ayrıca teknoloji ürünlerinin öğretim modelleriyle bütünleştirilmesi ve öğrenme ortamına olumlu yansımalarının gerçekleşmesi için öğrencilerin etkileşimde bulunabileceği uygun etkinlik yada ders materyallerinin hazırlanması gereklidir.

Ülkemiz öğrencilerinin gerek ulusal gerekse uluslararası sınavlarda fen bilimleri alanında aldığı sonuçlar hedeflenen seviyenin altında olduğunu göstermektedir. Bunun nedenleri arasında ise öğrencilerin derse karşı olumsuz tutumu ve düşük motivasyonu yer almaktadır. Bu tür uygulamalar eğitimin farklı kademelerinde yaygın ve etkili bir şekilde gerçekleştirilerek arzu edilen sonuçlara ulaşılabilir.

Fizik dersinde soyut kavramlar içermesinden dolayı öğrencilerin anlamakta güçlük çektiği bir çok konular mevcuttur. Bu tür konuların anlaşılabilmesi için öğrencilerin görsel ve zihinsel yapılarını harekete geçirebilecek animasyon, video görüntüleri ve simülasyonlar gibi materyallere derslerin desteklenmesi gereklidir. Ayrıca laboratuvar ortamında yapılamayan deneylerin etkileşimli ortamda sanal olarak gerçekleştirilmesi motivasyon ve başarıyı artıracaktır.

\section{Kaynakça}

Adıgüzel, A. \& Yüksel, İ. (2012). Evaluation of Teachers' Instructional Technologies Integration Skills: A Qualitative Need Analysis for New Pedagogical Approaches Necatibey Faculty of Education Electronic Journal of Science and Mathematics Education 6,1, 265-286.

Akbaş, O. \& Pektaş, H.M. (2011). The effects of using an interactive whiteboard on the academic achievement of university students Asia-Pacific Forum on Science Learning and Teaching, 12, 2, 1-19.

Balaban, S. J. (2002). Bilgisayar destekli öğretimde güdülenme kaynağı ve yetkinlik düzeyinin öğrenci başarı ve tutumları üzerindeki etkisi, Yayımlanmış Doktora Tezi, Anadolu Üniversitesi Sosyal Bilimler Enstitüsü, Eskişehir.

Bell, T., Urhahne D., Schanze S. \& Ploetzner R. (2010). Collaborative Inquiry Learning: Models, tools, and challenges, International Journal of Science Education, 32(3), 349377.

Büyüköztürk, Ş. (2010). Veri Analizi El Kitabl. Pegem A: Ankara. 
Blumenfeld, P.C.,Soloway, E., Man, R., Krajcik, J.S., Guzdial, M. \& Palincsar, A. (1991). Motivating Project-Based Learning: Sustaining the Doing, Supporting the Learning. Educational Psychologist, 26, 369-398.

Chai, C. S., Koh, J. H. L., Tsai, C. C., \& Tan, L. L. W. (2011). Modeling primary school preservice teachers' technological pedagogical content knowledge (tpack) for meaningful learning with information and communication technology. Computers \& Education, 57(1), 1184-1193.

Çolakoğlu, K. (Ed.). (1996). Serway Fizik 3. Ankara:Palme Yayıncılık.

de Jong, T. \&Van Joolingen, W. R.( 1998). Scientific discovery learning with computer simulations of conceptual domains. Review of Educational Research, 68(2), 179-201.

Dikici, M.(1994). Kuantum Fiziğine Giriş. Samsun:19 Mayıs Üniversitesi Yayınları.

Edelson, D.C., Gordin, D.N. \& Pea, R.D. (1999). Addressing the Challenges of Inquiry-Based Learning Through Technology and Curriculum Design. Journal of the Learning Sciences, 8, 3-4, 391-450.

Emre, İ., Kaya, Z., Özdemir, T. Y. \& Kaya, O. N. (2011). Akıllı Tahta Kullanımının Fen ve Teknoloji Öğretmen Adaylarının Hücre Zarının Yapısı Konusundaki Başarılarına ve Bilgi Teknolojilerine Karşı Tutumlarına Karşı Etkileri. 6th International Advanced Technologies Symposium (IATS'11), 16-18 May 2011, Elazığ, Turkey.

Gobert, J.D. \& Tinker, R.F.( 2004). Introduction to the issue. Journal of Science Education and Technology, 13(1), 1-5.

Jaakkola, T., Nurmi, S., \& Veermans, K. (2011). A comparison of students' conceptual understanding of electric circuits in simulation only and simulation-laboratory contexts. Journal of Research in Science Teaching, 48(1), 71-93. doi: 10.1002/tea.20386

Karasar, N. (2003). Bilimsel Araştırma Yöntemi. (12. Baskı). Ankara: Nobel Yayın Dağıtım

Keller, J. (2010). Motivational Design for Learning and Performance. New York: Springer.

Keselman, A. (2003). Supporting Inquiry Learning by Promoting Normative Understanding of Multivaiable Causality. Journal of Research in Science Teaching, 40, 9, 898-921.

Lai, H. J.(2010). Secondary school teachers'perceptions of interactive whiteboard training workshops: a case study from Taiwan. Educational Technology, 26 (4), 511-522.

Marzano, R.J. (2009). Teaching with interactive whiteboards. Educational Leadership, 67 (3), 80-82. 
Mcginn, M. K. \& Roth, W.M. (1999). Preparing Students for Competent Scientific Practice: Implications of Recent Research in Science and Technology Studies, Educational Researcher, 28, 3, 14-24.

Özdoğan, T., Kara, M., Gümüş, S. \& Orbay, M. (2011). Modern Fiziğe Giriş. Ankara: Pegem A Yayıncilik.

Perry, V.R. \& Richardson, C.P. (2001). The new mexico tech master of science teaching program: An exemplary model of inquiry-based learning. 31st ASEE/IEEE Frontiers in Education Conference, Reno.

Rushton, T. G. Lotter, C. \& Singer, J. (2011). Chemistry Teachers' Emerging Expertise in Inquiry Teaching: The Effect of a Professional Development Model on Beliefs and Practice. Journal of Science Teacher Education, 22, 23-52.

Rutten, N., Joolingen, W., Jan T. \& Van der V. (2012).The Learning Effects of Computer Simulations in Science Education. Computers \& Education 58,(2012) 136-153.

Saka, A. \& Akdeniz, A.R.(2006). Genetik Konusunda Bilgisayar Destekli Materyal Geliştirilmesi Ve 5E Modeline Göre Uygulanması. The Turkish Online Journal Of Educational Technology - Tojet, 5, 1.

Schwarz, C.V. \& White, B.Y.( 2005).Metamodeling knowledge: Developing students' understanding of scientific modeling. Cognition and Instruction, 23(2), 165-205.

Sencar, S., Y1lmaz, E. E., \& Eryılmaz, A. (2001). High school students' misconceptions about simple electric circuits. Hacettepe Üniversitesi Ĕ̈itim Fakültesi Dergisi, 21, 113-120.

Smith, H, J., Higgins, S., Wall, K. \& Miller, J.(2005). Interactive whiteboards: boon or bandwagon? A critical review of the literature. Journal of Computer Assisted Learning, $21,91-101$

Somyürek, S., Atasoy, B., \& Özdemir, S. (2009). What makes a board smart? Computers and Education, 53(2), 368-374.

Sünkür, M., Arabacı, İ.B., \& Şanlı, Ö. (2012). Akıllı tahta uygulamaları konusunda ilköğretim II. kademe öğrencilerinin görüşleri (Malatya ili örneği). E-Journal of New World Sciences Academy, 7 (1), 313-321.

Taş, E., Köse, S. \& Çepni, S.(2006). The Effects of Computer-Assisted Instruction Material on Understanding Photosynthesis Subject. International Journal of Environmental and Science Education, 1, 2,163 - 171. 
Timur, B. \& Kıncal, R.Y. (2010). İlköğretim 7. Sınıf Fen Bilgisi Dersinde Sorgulamalı Öğretimin Öğrenci Başarısına Etkisi, Türk Ĕ̆itim Bilimleri Dergisi 8, 1, 41-65.

Turgut, F. (1997). Eğitimde ölçme ve değerlendirme metotları. (10. Bask1). Ankara: Gül Yayınevi.

Türel, Y.K. (2012). Öğretmenlerin Akıllı Tahta Kullanımına Yönelik Olumsuz Tutumları: Problemler ve İhtiyaçlar. İlköğretim Online, 11(2), 423-439.

Ulukök, Ş, Çelik, H. \& Sarı, U. (2012). Basit Elektrik Devreleriyle İlgili Bilgisayar Destekli Uygulamaların Deneysel Süreç Becerilerinin Gelişimine Etkisi. Kuramsal Eğitimbilim Dergisi, 6(1), 77-101.

Vreman-de O.C. (2004). Student-generated assignments about electrical circuits in a computer simulation. International Journal Science Education, 26(7), 859-873.

Yıldırım, A., \& Şimşek, H. (2011). Sosyal bilimlerde nitel araştırma yöntemleri. Ankara: Seçkin Yayıncılık.

Yıldırım, H. İ., Yalçın, N., Şensoy, Ö., \& Akçay, S. (2008). İlköğretim 6., 7. ve 8. sınıf öğrencilerinin elektrik akımı konusunda sahip oldukları kavram yanılgıları. Kastamonu Ĕ̈itim Dergisi, 16(11), 67-82.

Zacharia, Z. (2003). Beliefs, Attitudes, and Intentions of Science Teachers Regarding the Educational Use of Computer Simulations and Inquiry-Based Experiments in Physics. Journal of Research in Science Teaching, 40(8), 792-823.

Willis, B. (1994). Distance Education-Strategies and Tools. Educational Technology Publications, http://www.uidaho.edu/evo/dist3.html.

Ek 1 Modern Fizik Akademik Başarı Testinden Örnekler 
4. Siyah cismin ışıması ile ilgili deneysel sonuçları ve klasik fizik sonuçlarını gösteren ışımanın şiddeti ve dalga boyu grafiğine göre, aşağıdaki yorumlardan hangileri doğrudur? I. Siyah cismin yaptığı 1şıma; kızı̈ötesi- görünür bölgemorötesi bölgelerini kapsar.

II. Klasik fiziğin büyük dalga boylu ışımaları ile deneysel sonuçlar uyumludur.

III. Deneysel sonuçlara göre, şiddet maksimum olduğunda 1şımanın dalga boyu da maksimum olur.
A) Yalnız I
B) Yalnız II
C) I ve II
D) I ve
III E) I, II ve III

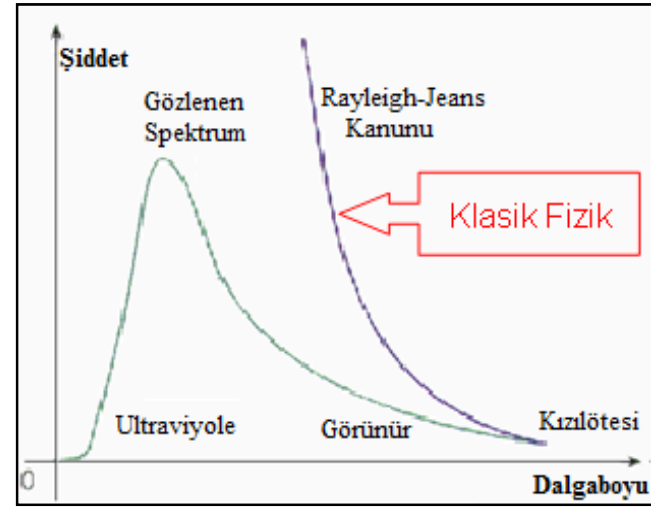

10. Bir metale düşürülen $K, L$ ve $M$ 1şıklarının şiddetleri ile fotoelektronlarının kinetik enerjileri tablodaki gibidir. Buna göre, 1şıkların $\lambda_{\mathrm{K}}, \lambda_{\mathrm{L}}, \lambda_{\mathrm{M}}$ dalga boylarının büyüklükleri arasında nasıl bir ilişki vardır?
A) $\lambda_{\mathrm{K}}>\lambda_{\mathrm{L}}=\lambda_{\mathrm{M}}$
B) $\lambda_{\mathrm{L}}=\lambda_{\mathrm{M}}>\lambda_{\mathrm{K}}$
C) $\lambda_{\mathrm{K}}>\lambda_{\mathrm{L}}>\lambda_{\mathrm{M}}$
D) $\lambda_{\mathrm{M}}>\lambda_{\mathrm{L}}>\lambda_{\mathrm{K}}$
E) $\lambda_{\mathrm{K}}=\lambda_{\mathrm{L}}>\lambda_{\mathrm{M}}$

\begin{tabular}{|c|c|c|}
\cline { 2 - 3 } \multicolumn{1}{c|}{} & Işık Şiddeti & Kinetik Enerji \\
\hline $\mathrm{K}$ & $\mathrm{I}$ & $2 \mathrm{E}$ \\
\hline $\mathrm{L}$ & $\mathrm{I}$ & $\mathrm{E}$ \\
\hline $\mathrm{M}$ & $2 \mathrm{I}$ & $\mathrm{E}$ \\
\hline
\end{tabular}

13. Sezyum metalinin iş fonksiyonu (bağlanma enerjisi) $3,04 \times 10^{-19} \mathrm{~J}$ 'tur. Dalga boyu $5 \times 10^{-7} \mathrm{~m}$ olan bir 1 şık sezyum metali üzerine düşürüldüğünde sökülen fotoelektronların kinetik enerjisini kaç joule olur? $\left(\mathrm{h}=6,62 \times 10^{-}\right.$ $\left.{ }^{34} \mathrm{~J} . \mathrm{s}, \mathrm{c}=3 \times 10^{8} \mathrm{~m} / \mathrm{s}\right)$
A) $8,3 \cdot 10^{-20}$
B) $9,3 \cdot 10^{-20}$
C) $11,3 \cdot 10^{-20}$
D) $12,3 \cdot 10^{-20}$
E) $13,3 \cdot 10^{-20}$

15. Şekilde durgun bir elektron ile bir X-1şını fotonunun çarpışması gösterilmiştir. Buna göre;

I. Saçılan fotonun momentumu azalmıştır.

II. Gelen foton mor 1şık ise saçılan foton yeşil 1şık olabilir.

III. Gelen foton yeşil 1şık ise saçılan foton mor 1şık olabilir. ifadelerinden hangileri doğrudur?
A) Yalnız I
B) Yalnız III
C) I ve II
D) I, II ve III

E) II ve III

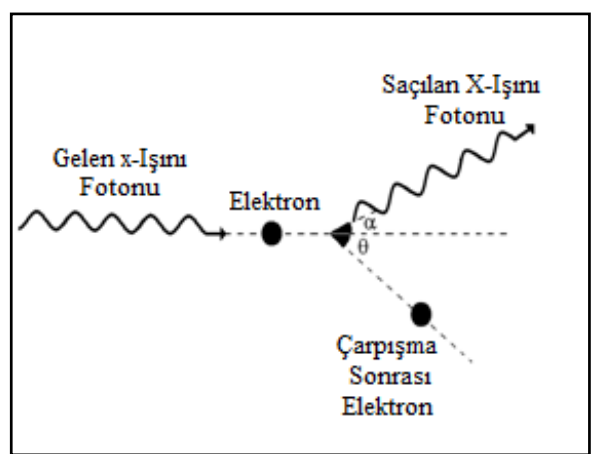

Ek 2 Etkileşimli Tahta Uygulamaları Durum Değerlendirme Formu 
Etkileşimli tahta kullanımının etkililiği ve verimliliğinin belirlenmesi amacıyla sizlere birtakım sorular sorulmaktadır. Öncelikle vereceğiniz bilgiler için teşekkür ederim. Bu sorulara cevap verirken düşüncelerinizi açıklıkla dile getirmenizin oldukça önemli olduğunu vurgular, ilgi ve katılımınız için teşekkür ederim.

1. Etkileşimli tahtanın derslerinizde kullanışlılığı ve yararlılığı konusunda neler söyleyebilirsin?

2. Etkileşimli tahta, dersi anlama düzeyine ve öğrenmene ne gibi katkı sağladı?

3. Etkileşimli tahta kullanımı derse karşı ilgi ve motivasyonunu nasıl etkiledi?

4. Öğretmen olduğunda derslerinde etkileşimli tahta kullanmak ister misin? Neden?

5. Simülasyon uygulamaları senin için faydalı oldu mu? Olduysa ne gibi faydaları olduğunu belirtiniz.

6. Simülasyon uygulamalarını öğretmen olduğunda derslerinde kullanmak ister misin? Neden?

7. Etkileşimli tahta ile yürütülen dersler ile önceki derslerini karşılaştırdığında ne gibi farklılıklar görüyorsun? Farklılık var ise iyi yönde mi kötü yönde mi? Neden?

8. Etkileşimli tahtanın derslerde etkili kullanımı için uygun materyal (animasyon, video görüntüleri, simülasyon, çalışma yaprakları vb.) hazırlanmalı mıdır? Neden? 


\section{Ek 3 Deney grubu için hazırlanan öğretim materyalinden örnekler}
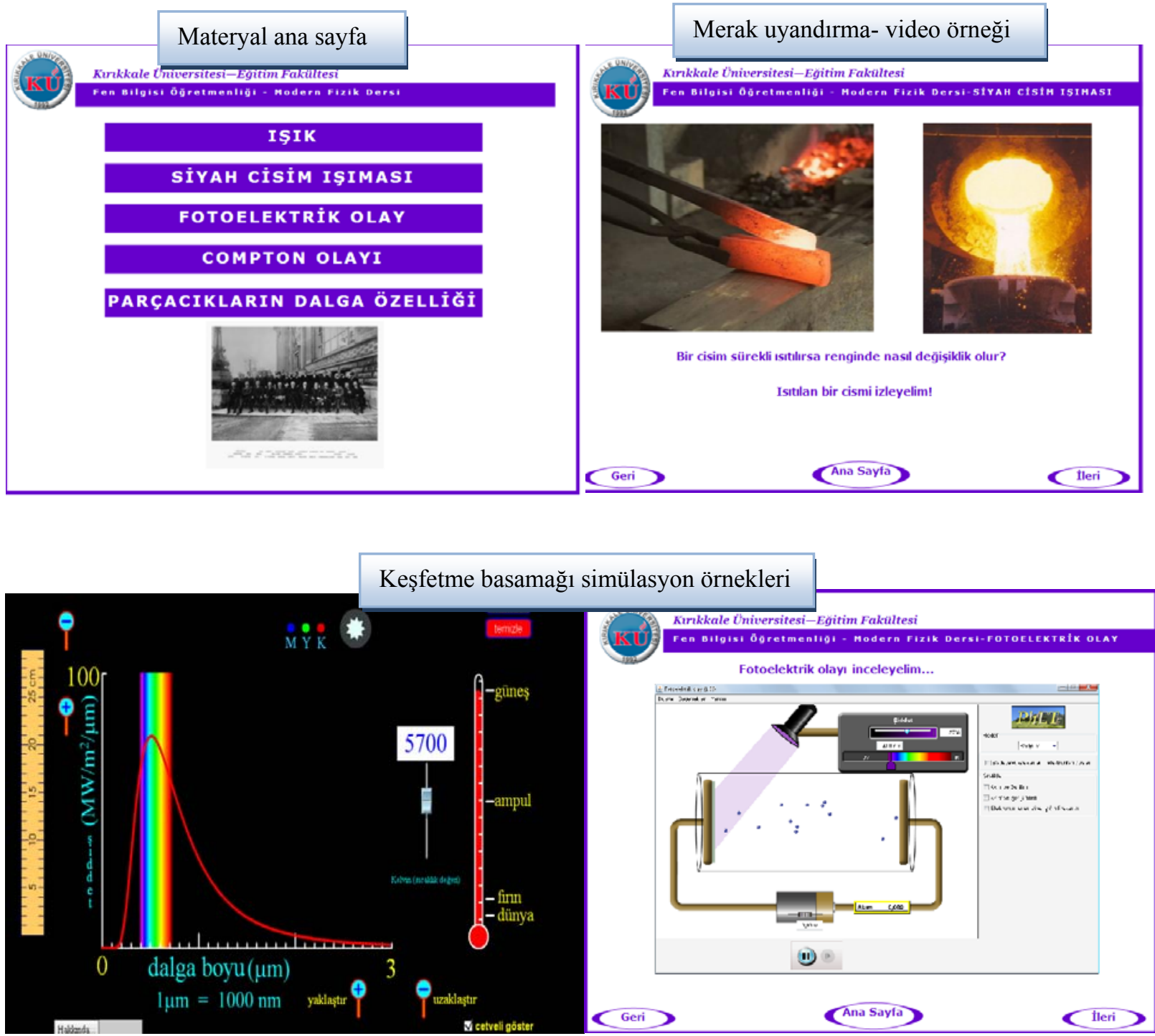

Açıklama basamağı sunum ve animasyon örneği

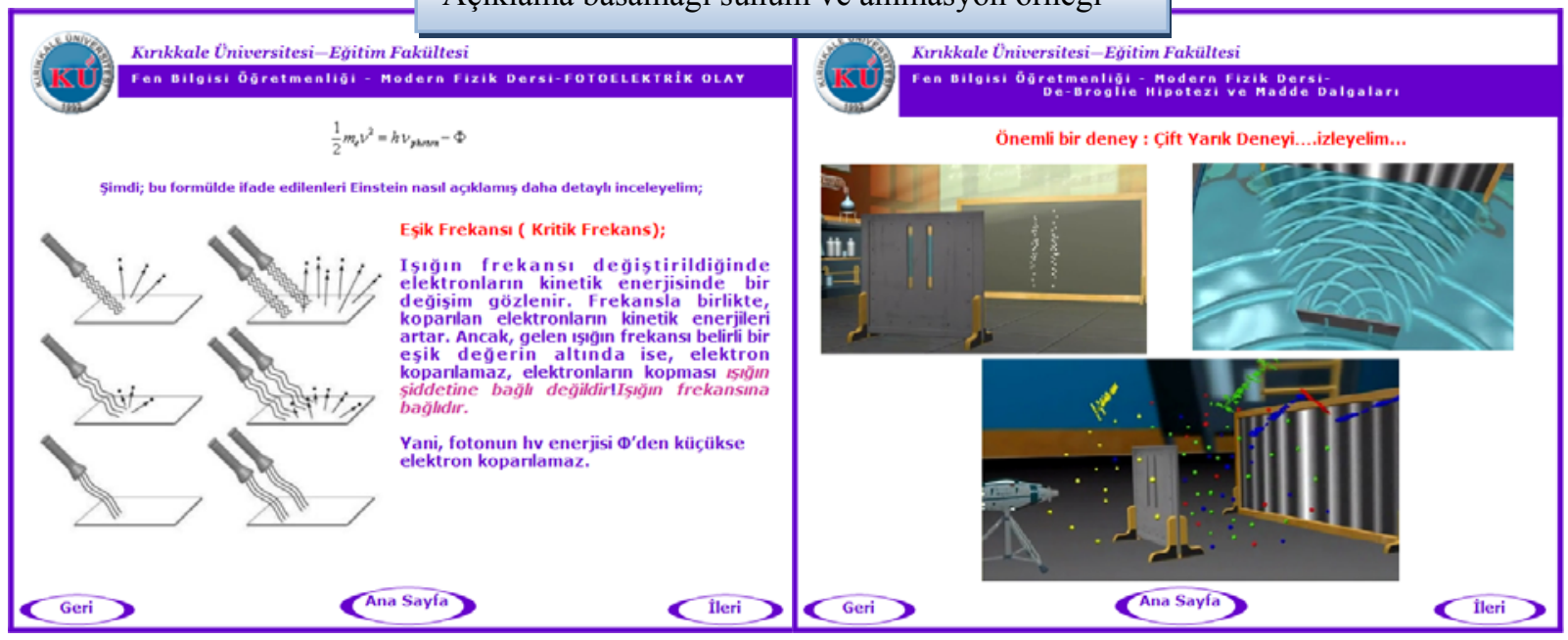


Genişletme basamağı örnekleri
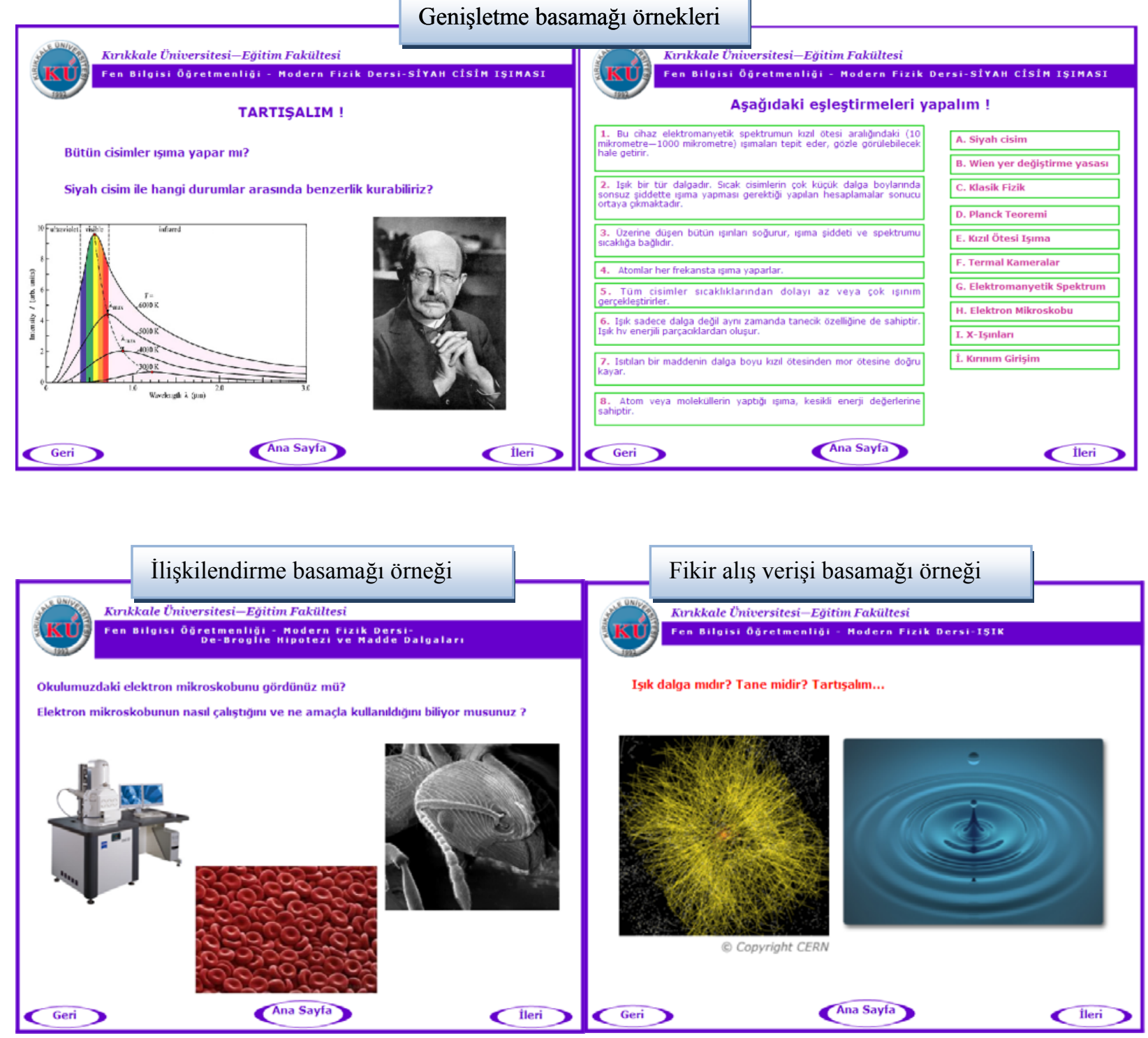

Değerlendirme basamağı örnekleri

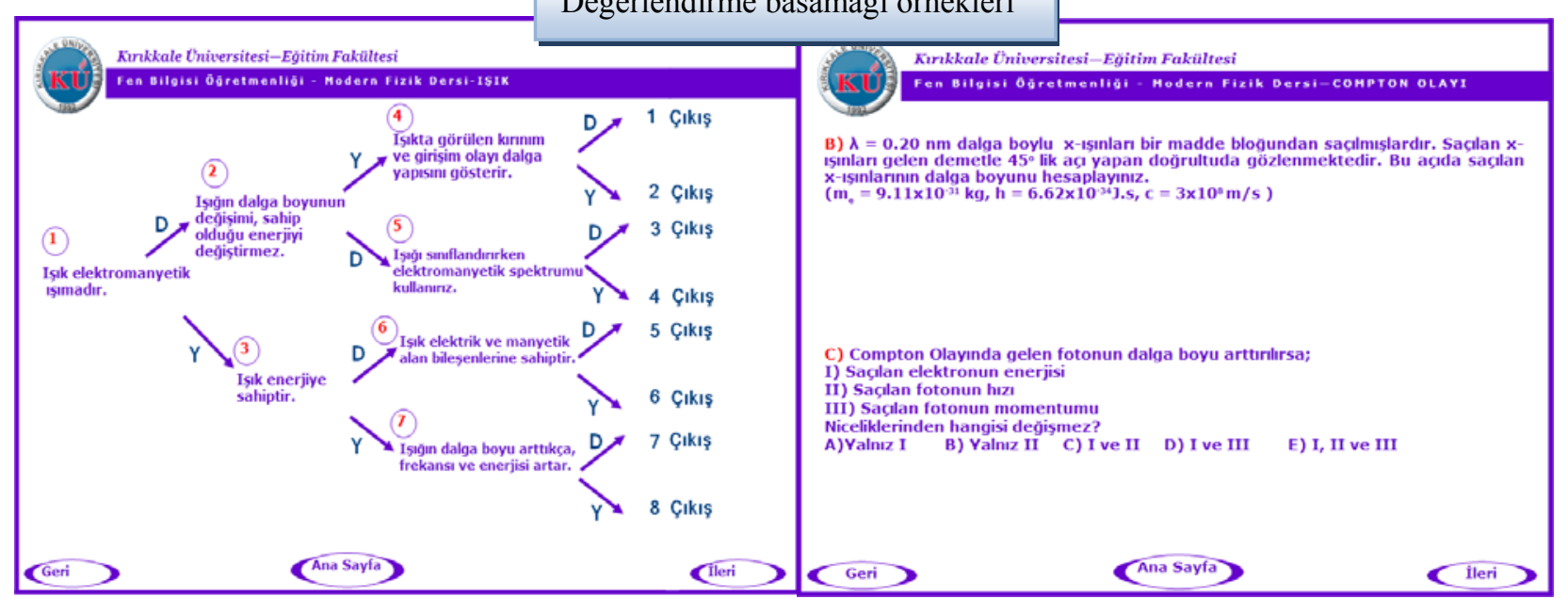

